SECURE BICYCLE PARKING:

Downtown Toronto Office Buildings

By

Adam Sweanor

Trent University BBA (2012)

\author{
A MRP \\ Presented to Ryerson University \\ In partial fulfillment of the \\ Requirements for the degree of \\ Master of Planning \\ In the Program of \\ Urban Development
}

Toronto, Ontario, Canada, 2015

CAdam Sweanor 2015 


\section{DECLARATION}

I hereby declare that I am the sole author of this MRP. This is a true copy of the MRP, including any required final revisions. I authorize Ryerson University to lend this MRP to other institutions or individuals for the purpose of scholarly research. I further authorize Ryerson University to reproduce this MRP by photocopying or by other means, in total or in part, at the request of other institutions or individuals for the purpose of scholarly research. I understand that my MRP may be made electronically available to the public. 


\title{
SECURE BICYCLE PARKING: Downtown Toronto Office Buildings
}

CAdam Sweanor 2015

\author{
Master of Planning \\ in \\ Urban Development \\ Ryerson University
}

\section{ABSTRACT}

Road congestion, urban intensification, environmental degradation and health concerns among other factors have led to an increase in cycling rates in Toronto. This increase in the cycling modal share, and a public policy environment that wishes to facilitate additional cycling, has in turn caused an increase in demand for associated facilities including secure bicycle parking. This paper examines the current provision of secure bicycle parking in downtown Toronto office towers and formulates a best practices standard to inform and encourage a more widespread adoption for a diverse range of office building size, location, and construction date. Many office buildings in downtown Toronto were built prior to the creation of zoning for bicycle parking, thus this paper focuses its recommendations on the implementation of future secure bicycle parking in the downtown core.

\section{KEY WORDS}

Bicycling; Cycling; Toronto, Ontario, Canada; Secure Bicycle Parking; End-of-Trip Facilities; Downtown Office Towers; Active Transportation 


\section{ACKNOWLEDGEMENTS}

I would first like to acknowledge my supervisor Dr. Chris De Sousa. His guidance provided me direction throughout the writing and researching process. This guidance helped me through the hiccups I encountered in my data collection and helped me put forward a final product that I am very proud of.

I would also like to thank my second reader, David Tomlinson from the City of Toronto. His experience as a planner addressing bicycle parking in the Transportation Services Department provided me with valuable direction throughout my writing process.

Additionally I am thankful for the assistance my classmates Zibby Petch and Alicia Kingdon gave me on the creation of my researched office building map. Their superior knowledge of GIS was an appreciated contribution to my paper.

I would also like to thank my colleague Michael Lee and my father David Sweanor for reading through my initial draft and providing me with valuable feedback. Their outside perspectives provided important insight and ultimately made my paper more clear and concise.

Finally I would like to thank my mother Linda Huehn and girlfriend Katie Vatri for their support throughout my researching and writing process. 


\section{TABLE OF CONTENTS}

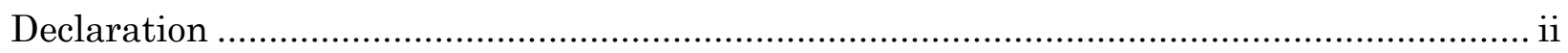

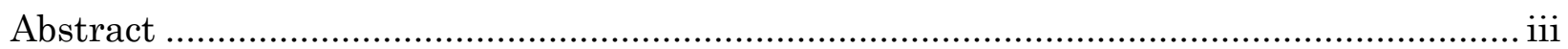

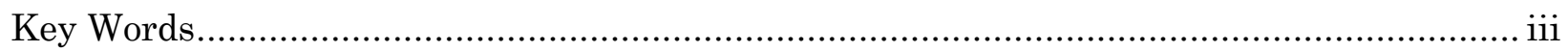

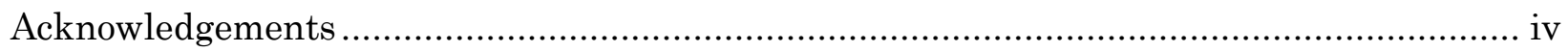

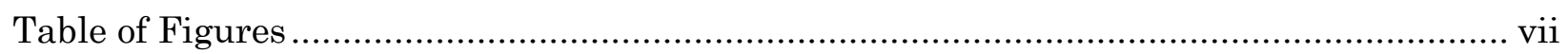

Introduction and Background ............................................................................. 1

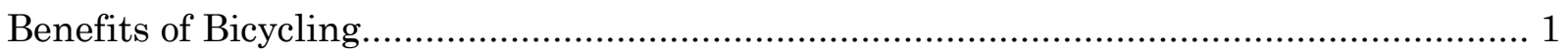

Types of Bicycle Parking......................................................................................... 3

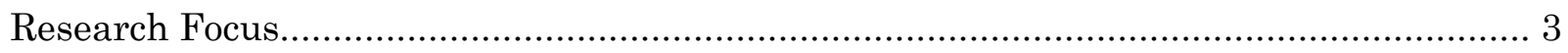

Existing Toronto Bicycle Network ........................................................................... 4

Importance of Zoning By-Laws....................................................................... 5

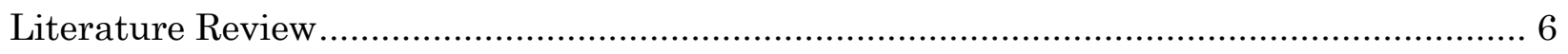

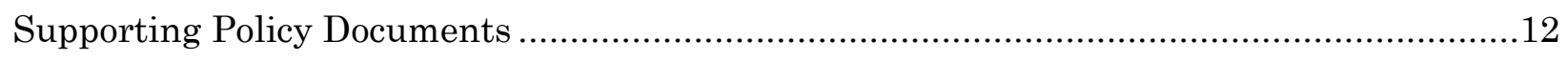

Toronto's Official Plan ............................................................................................ 12

The Provincial Policy Statement .................................................................. 12

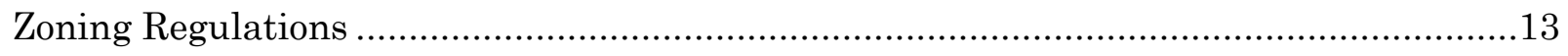

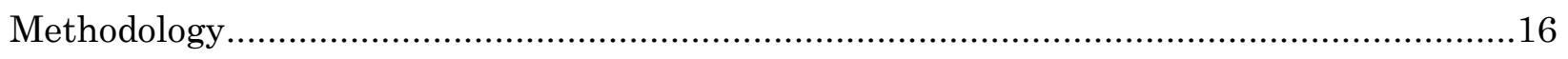

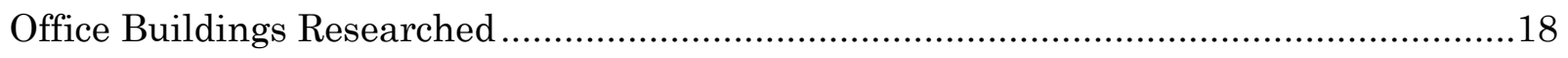

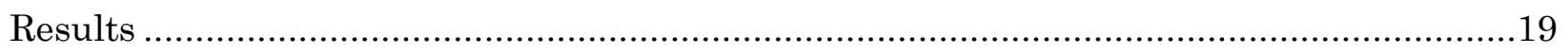

1) 88 Queens Quay West.............................................................................. 19

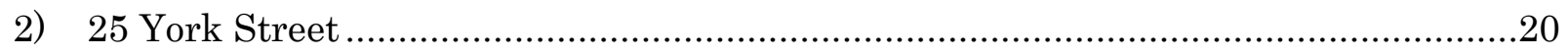

3) Royal Bank Plaza ....................................................................................21

4) Brookfield Place ......................................................................................22

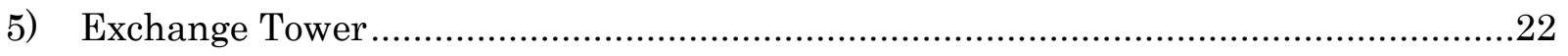

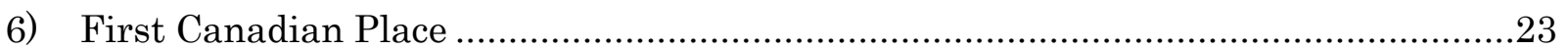




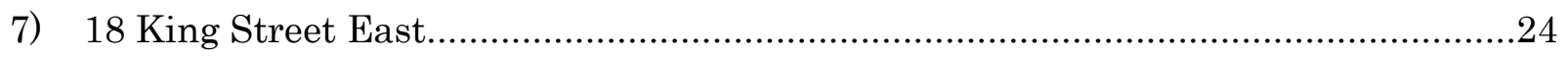

8) Adelaide Place..........................................................................................24

9) Richmond Adelaide Centre ...........................................................................225

10) Bay Adelaide Centre.............................................................................26

11) One Queen Street East............................................................................27

12) Toronto Eaton Centre Towers ...................................................................28

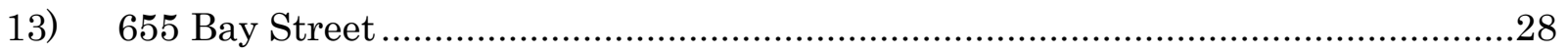

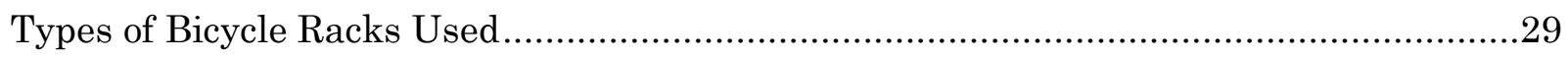

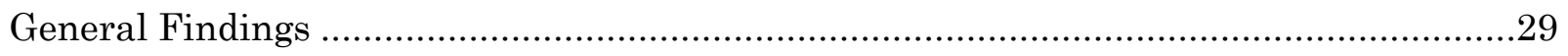

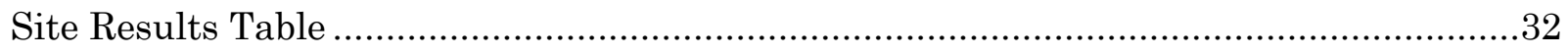

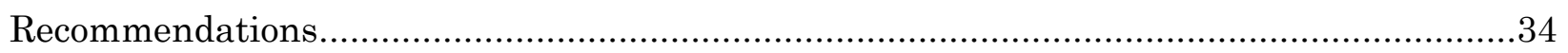

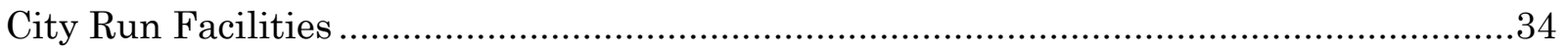

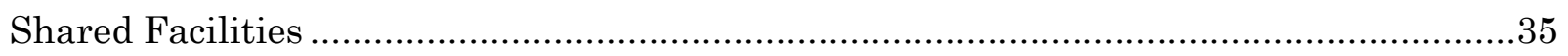

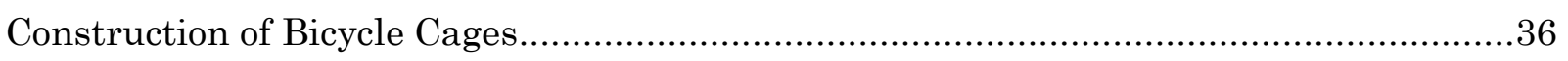

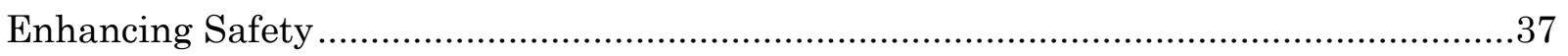

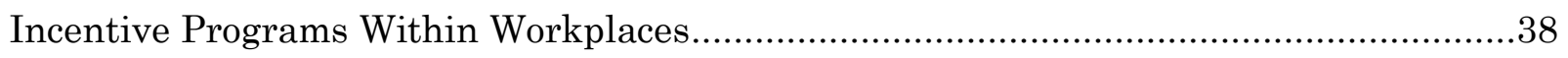

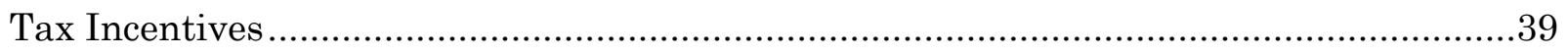

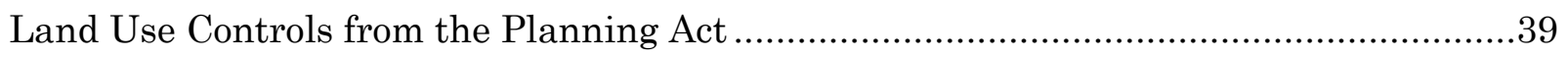

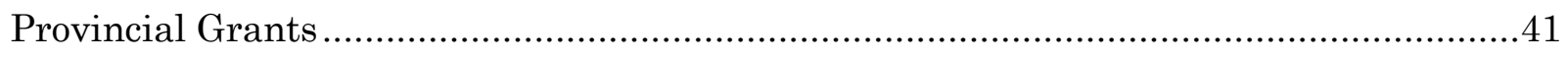

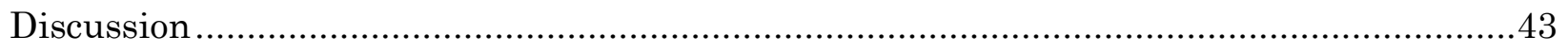

Different Recommendations for Different Facilities ...............................................44

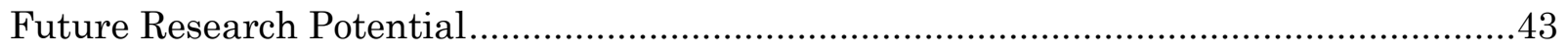

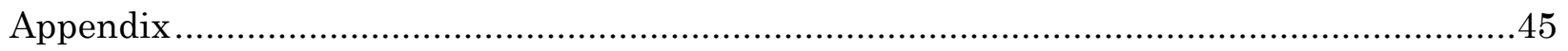

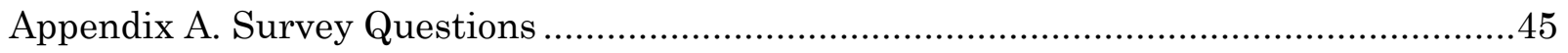

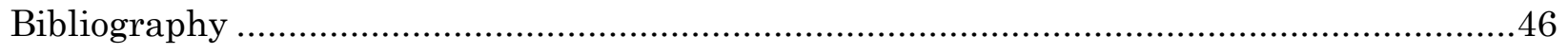




\section{TABLE OF FIGURES}

Figure 1: Secure bicycle cage beside unsecure parking Richmond Adelaide Centre............. 3

Figure 2: Secure bicycle room Bay Adelaide Centre....................................................... 6

Figure 3: Secure bicycle room 25 York Street...............................................................20

Figure 4: Outdoor secure bicycle cage Royal Bank Plaza...............................................21

Figure 5: Secure bicycle cage Adelaide Place...............................................................24

Figure 6: Bicycle lock storage wall Bay Adelaide Centre .................................................26

Figure 7: Traditional Bicycle Rack Toronto Eaton Centre .............................................28

Figure 8: Upright Bicycle Racks 25 York Street............................................................29

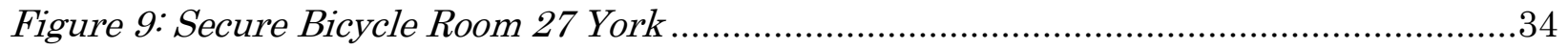




\section{INTRODUCTION AND BACKGROUND}

Traffic congestion has become a major point of contention in many North American metropolitan regions, creating an impetus for a paradigm shift away from the personal automobile. This congestion has also coincided with increasingly sedentary lifestyles, contributing to a rise in obesity rates. Both of these issues represent major political, health, and economic concerns in terms of urban stability and sustainability. Due to the complexity of Metropolitan regions, combatting this problem will require a multi-faceted approach. One such approach includes facilitation of active transportation through the provision of secure bicycle parking facilities, which when paired with safe on-street infrastructure, can reduce traffic congestion while increasing overall health and fitness.

\section{Benefits of Bicycling}

Bicycling, and other forms of active transportation, helps to achieve a multitude of public health objectives, positively impacting the population. There is strong evidence that bicycling, as a form of regular moderately intense physical activity, among adults can lower the risk of early death, heart disease, stroke, type-2 diabetes, high blood pressure, and prevalence of weight gain, while also enhancing cardiorespiratory and muscular fitness, and delivering many other associated benefits (Oja, et al., 2011; Frank, Engelke, \& Schmid, 2003). Achieving large-scale macro public health benefits can come from micro individual change, such as low intensity utilitarian bicycling.

Beyond the benefits to physical health increased rates of cycling can also positively contribute to a populations' mental health. Exercise has been shown to improve a populations' mental wellbeing, predominately through improved mood and self-perceptions. This has also been shown to provide effective treatment for clinical depression and anxiety (Fox, 1999). Thus supporting initiatives that promote cycling can provide both physical and mental health benefits to the population.

These benefits are often forgone through public perception surrounding the inherent dangers of riding a bicycle in a city. Risk factors such as air pollutants and dangers sharing the road with other automobiles are often misrepresented. Studies have shown that, while there are risk factors associated with cycling, the health benefits greatly outweigh these risks by a factor of 20 to 1 (Board of Science of the British Medical Association, 2012). 
In addition bicycling can contribute to a reduction in air pollution, carbon emissions, congestion, noise, traffic danger, and other harmful societal and environmental impacts associated with the automobile (Pucher, Dill, \& Handy, 2010; Environment Canada, 2013). Specifically in the Greater Toronto Area transportation represented the largest contribution of carbon dioxide equivalent, ahead of stationary (electric and gas), industrial and waste. Out of the 53,850,000 $\mathrm{CO}_{2} \mathrm{e}$ produced in 2009 transportation represented $48.3 \%$, with personal vehicles accounting for $22.6 \%$ of that total (Toronto and Region Conservation Authority and Greater Toronto CivicAction Alliance, 2011). With personal vehicles representing such a large contribution to greenhouse gases, providing alternative modes can reduce negative environmental impacts. Promoting a transportation modal shift away from personal vehicles, towards active transportation such as bicycling, can reduce the air pollutants and greenhouse gases present in the Greater Toronto Area.

These net societal benefits have pushed governments and public health agencies to advocate for additional facilitation of cycling, helping to ensure continued rapid growth in active transportation. This paradigm shift towards promoting healthy forms of transportation is reinforced through measures such as Toronto's Official Plan and Ontario's Provincial Policy Statement (City of Toronto, 2010; Ministry of Municipal Affairs and Housing , 2014). These programs and policies can include infrastructure projects such as segregated bicycle lanes or bicycle parking, or educational programs such as bicycle safety training and school cycling programs.

Each initiative serves a crucial role in creating a meaningful transition to bicycling as a more widely accepted and utilized mode of transportation. This also illustrates that advocacy for cycling is a multi-faceted initiative, with many important avenues that must be considered to have maximal effect. Focusing on each separate program and initiative to increase cycling would be beyond the scope of this project, thus the focus of this paper will be on one aspect; secure bicycle parking in downtown office towers. Bicycle parking is an important component of a comprehensive system of cycling infrastructure, but as with any other planned infrastructure project, for these facilities to have maximal effect they must be accompanied by other initiatives, such as bicycle lane implementation and upgrades. Secure bicycle parking and associated amenities will provide utilitarian cyclists with the opportunity to place their bicycle in a secure facility, and potentially have access to various amenities. Secure bicycle parking facilities will serve as added incentive alongside the various other 
policies and programs to incentivise bicycling. These policies and programs include language in both the Provincial Policy Statement and Toronto Official Plan that support active transportation and specifically bicycling.

\section{Types of Bicycle Parking}

In the provision of secure bicycle parking facilities it is imperative to understand the differences between long-term and short-term bicycle parking. Short-term bicycle parking can involve outdoor stands or racks with limited weather and security protection, or indoor racks not secured in a separate facility. They are provided free of

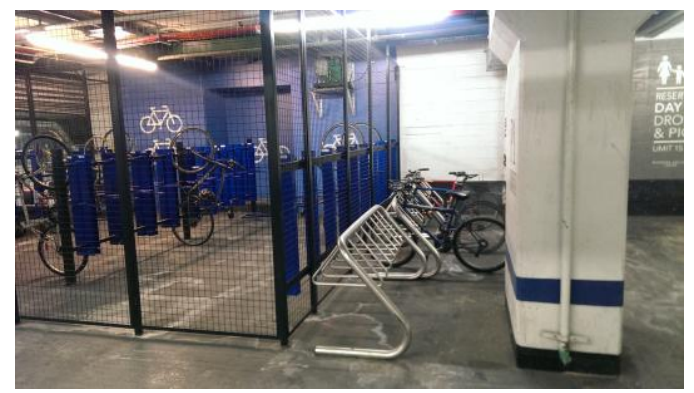

Figure 1: Secure bicycle cage beside unsecure parking Richmond Adelaide Centre charge to any member of the population and are intended for short stays, providing ease of access (Transport Canada, 2010). Long-term parking involves partial or full enclosures or indoor parking facilities with limited public access. These facilities will ideally provide added weather and security protection compared with short-term facilities. Secure end-of-trip facilities can also provide the added benefit of complementary services including lockers, showers, change rooms, and bicycle repair stands and tools (Transport Canada, 2010).

\section{$\underline{\text { Research Focus }}$}

Researching the provision of secure bicycle parking required the acquisition of primary data focused on the downtown core of Toronto. The high number of office towers in Toronto made it important to narrow the focus of the research (Arnoldi, West, \& Gilligan, 2014). Working under both time and resource constraints focused the research on a manageable sample of office towers. These building operators provided a good cross section of downtown office buildings, with a diverse age, size, and location within the downtown core and al utilizing a range of different secure bicycle parking facilities.

The office buildings examined as part of the research are located in central downtown in Ward 27 and 28 in the City of Toronto. Ward 27 had a population of 69,635 and Ward 28 had a population of 66,585 as of 2011 (City Planning Division, 2015). This population is augmented by over 446,000 jobs in Downtown Toronto, with the majority falling within the downtown core, making up the largest and most accessible employment centre in the region (Ostler, 2014). With the differential between the residential population and work population 
it can be inferred that downtown sees a high volume of commuter travel. The study area provides a high density of commercial office space within close proximity to residential housing, making trips by bicycle more feasible in the area. This was important factor in the geographic scope of the project given the land use differences throughout the City of Toronto. Choosing one specific area, the downtown core, allows more relational data to be collected without having to account for density or transportation mode differences across the entire city. These buildings are in an environment conducive to shorter commute distances, increasing the feasibility of active transportation. Shorter distances with enhanced on route cycle networks, combined with lower vehicle speeds makes cycling a more viable method of commuting.

The research questions this paper will address focus on the current provision of secure bicycle parking in Downtown Toronto. The questions include:

- Is there an adequate supply of secure bicycle parking to meet current demand?

- Is demand for secure bicycle parking increasing?

- What sort of facilities are provided?

- What are some barriers to implementing secure bicycle parking?

These questions will provide a more encompassing view of the existing secure bicycle parking infrastructure in Downtown Toronto, and the views of the different management companies pertaining to the use of their bicycle facilities. This will ultimately help inform recommendations for the future of secure bicycle parking and provide the necessary framework for potential further research expansion.

\section{Existing Toronto Bicycle Network}

Over the past two decades Toronto has enhanced its bikeway network. These projects have created a safer environment for bicycling, leading to an increase in the bicycle transportation modal share in the city (Ipsos Reid, 2010). The network has been expanded to include sharrows (road markings to signal automobiles and bicycles to share the lane) and painted bicycle lanes on streets including Bay and College Street, segregated bicycle lanes on streets including Wellesley and Sherbourne Street, contraflow bicycle lanes on streets including Shaw and Simcoe Street, and the expansion of an extensive trail system. These facilities and the associated increase in bicyclists have made other road users more aware of cyclists on streets without designated cycling infrastructure. Creating a safer more accessible 
bicycle network will work synergistically with secure bicycle parking to promote a shift to a more sustainable and healthy mode of transportation.

\section{Importance of Zoning By-Laws}

Implementing secure bicycle parking that is demand sensitive and capable of meeting a reasonable standard across separate buildings and operators requires, among other things, the implementation of specific zoning by-laws. Secure bicycle parking by-laws are a relatively new phenomenon in the amalgamated City of Toronto with the City-wide By-law 569-2013 being enacted on May 9, 2013 (City of Toronto, 2013). Included in this is Chapter 230 Bicycle Parking Space Regulation, with the latest version dated August 19, 2014 (City of Toronto, 2013). Before the current zoning regulations were implemented they differed based on the pre-amalgamated city (Cycling Infrastructure and Programs, 2008). This research paper focuses on the current and anticipated growth in secure parking facilities among downtown office towers, with an understanding that the majority will have been constructed or renovated prior to the introduction of zoning for secure bicycle parking in Toronto. The research focuses specifically on several existing facilities as a best practice analysis of implementation possibilities. The variables will include current facilities (secure parking and amenities), demand for the facilities, and future direction.

The City of Toronto, along with many other large North American cities, has become increasingly open to the promotion of active modes of transportation in the past decade. In Toronto this has included the introduction of several prominent on street bicycle lanes, recreational trails, and City of Toronto secure bicycle parking facilities. With more individuals opting to travel via active means there has been greater pressure to provide amenities to facilitate this modal shift, and such amenities can encourage yet more bicycling. This virtuous cycle, coinciding with the introduction of secure parking zoning regulations, has facilitated a pattern of change towards a more bicycle friendly environment. 


\section{LITERATURE REVIEW}

Increasing the rate of bicycling has been shown in a multitude of studies to provide a net societal benefit. These include environmental benefits, health benefits, and economic benefits (Board of Science of the British Medical Association, 2012; Fox, 1999; Frank, Engelke, \& Schmid, 2003). Governments, businesses, not for profits, and individuals have recognized this benefit and have been advocating to increase cycling over the past several decades in North America. In 2006 commuters in Canada traveled a median distance of 7.6 kilometers, illustrating that a large portion of the population have commute distances that would be feasible via active transportation (Statistics Canada, 2006). Creating safer routes through on street cycling facilities has the potential to significantly increase the adoption of bicycling. Evidence for on-street cycling facilities suggests that segregated cycle lanes and independent cycle pathways have the greatest impact on increasing the propensity to bicycle (Ahmed, Rose, \& Jakob, 2013; Hunt \& Abraham, 2007).

While these on-street facilities are a crucial element to increasing cycling, there are many other important elements to consider. Evidence has shown that secure bicycle parking facilities provide an incentive towards the promotion of utilitarian cycling (Wardman, Tight, \& Page, 2007; Buehler, 2012; Heinen, Van Wee, \& Kees, 2010). Providing secure bicycle parking at places of employment and transportation hubs greatly increases the propensity for individuals to cycle to their

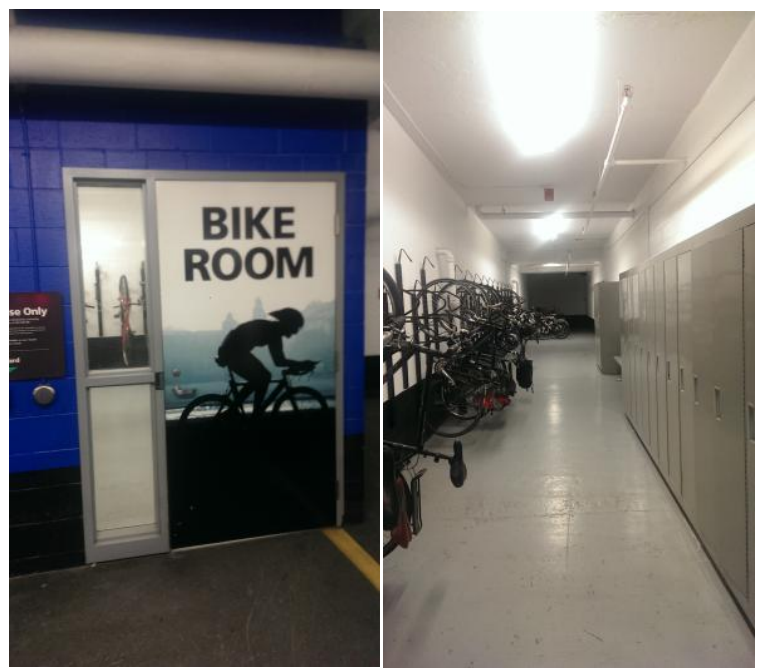

Figure 2: Secure bicycle room Bay Adelaide Centre destinations (Rietveld, 2000; Martens, 2007;

Buehler, 2012). Given the scope of this paper, the literature review will focus on the implementation of secure bicycle parking and its benefits and barriers.

Secure bicycle parking facilities can take many forms that fit with the individual characteristics of each site. Bicycle enclosures in multi-story parking garages that require a smart card or key to gain access are popular in residential and office buildings (Third Wave Cycling Group, 2010). Secure bicycle parking facilities in parkades are excellent for 
commuters and residents of the specific buildings but lack the visibility and accessibility for other destinations such as shopping centres. Office towers and residential buildings can also retrofit a room with bike racks and other amenities to facilitate bicycle storage (San Francisco County Transportation Authority, 2013; Cycling Infrastructure and Programs, 2008).

Another form of parking facility, the bicycle locker, provides a secure enclosure for one bicycle. Bicycle lockers are weather protected, and are operated by a controlled access system (Cycling Infrastructure and Programs, 2008; The Government of Western Australia, 2013). These facilities work best at in low demand areas when space is not significantly constrained, such as certain transit stops. Due to the capacity constraint of one bicycle per locker they are not very space efficient, limiting their integration into demand intensive locations (Third Wave Cycling Group, 2010).

A bicycle station facility would be better suited for demand intensive locations. These facilities can provide on-demand secure bicycle parking facilities or long-term memberships depending on the operation model (Third Wave Cycling Group, 2010). They can be staffed or unstaffed along with providing additional amenities (The Government of Western Australia, 2013). Capacity can be maximized through the integration of stacked bicycle racks or wall mounted racks (Cycling Infrastructure and Programs, 2008).

The research in this paper will predominantly focus on bicycle stations or rooms provided at end-of-trip locations. Bicycle lockers, while they are the most secure, are not efficient users of space for high demand high use locations, ultimately making them not optimal for office buildings where space is at a premium (San Francisco County Transportation Authority, 2013).

The provision of secure bicycle parking accompanied by other amenities such as showers have been shown in Toronto, Edmonton, and Washington, DC to positively influence bicycle ridership (Buehler, 2012; Hunt \& Abraham, 2007). A 1999 study in Toronto of 49,000 cyclists found secure parking to be the second most important factor in choosing to cycle, with bicycle lanes being the most important factor. The Toronto study also found that 33,000 Toronto cyclists identified shower and change facilities as an important feature (Cycling Infrastructure and Programs, 2008). The study in Edmonton concluded that secure parking was a greater motivator than showers and other amenities, but they all contributed to a positive influence on cycling rates (Heinen, Van Wee, \& Kees, 2010). In Edmonton the 
implementation of secure parking carried the equivalent perceived benefit of a 26 -minute reduction in travel time in mixed-traffic (Buehler, 2012). The Washington study arrived at the same conclusion, highlighting the importance of secure parking and to a lesser extent showers for an increased cycling modal share (Hunt \& Abraham, 2007). Ultimately regardless of the facility, simply providing secure bicycle parking can improve the cycling modal share.

In order to gain the full benefit of secure bicycle parking facilities the infrastructure must be conveniently located and easily accessible (Sully, 2006; Lefrancois, 2014). This entails placing bicycle parking in high demand areas, in close proximity to intended destinations, and with a connection to designated bicycle routes (Lefrancois, 2014). Hossain et al. studied the significance of location and accessibility, highlighting the importance of providing both short-term and long-term bicycle parking. This would include both indoor and outdoor facilities to serve employees, as well as others who cycle to the destination on a shortterm infrequent basis (Hossain, Botma, Vandebona, \& Kiyota, 2003). A study in San Francisco found that over $80 \%$ of both male and female respondents were more likely to bicycle if a secure end-of-trip facility was provided, thus highlighting the importance of including secure bicycle parking in addition to unsecured parking (San Francisco County Transportation Authority, 2013).

Free bicycle parking in these scenarios removes a cost barrier and ultimately leads to a higher cycling adoption rate (Hossain, Botma, Vandebona, \& Kiyota, 2003). This can be accomplished through placing bicycle parking in the public right of way or providing secure bicycle parking at no charge to community members or to employees of the associated buildings (Transport Canada, 2010). Contrarily, if car parking is provided for free it reduces the cycle modal share to the destination. In Washington, DC the provision of free car parking reduced cycling rates by 70 percent (Buehler, 2012).

To optimize the use of secure bicycle parking facilities they should adhere to certain design characteristics. The facilities in question would serve employees of a particular building so public access is not a determining factor. The station must still retain visibility, which can include management ensuring the employees are aware of the facility and its amenities (Sully, 2006) (Lefrancois, 2014). In maintaining this visibility it is imperative to include way-finding signage to the facility, as well as include the facility location 
electronically for increased accessibility to the information (Sully, 2006; Urban Systems, 2011; Lefrancois, 2014). As with any secure facility security is an important consideration. For office buildings staffed facilities are not likely to be economically feasible, leading to security cameras providing the most cost effective form of security (Sully, 2006). Finally an important consideration is to ensure that the facility can accommodate additional future demand, either through excess existing capacity or available expansion space (Lefrancois, 2014).

Additional motivators include financial incentives for commuting via bicycle. Including modest financial incentives alongside the secure bicycle parking and other amenities increases the likelihood that cycling can emerge as a much more significant mode with an appreciable decrease in car share (Wardman, Tight, \& Page, 2007). Winters et al. highlighted incentives and bicycle parking as moderate influences on the likelihood to cycle (Winters, Davidson, Kao, \& Teschke, 2011). Other positive incentives beyond financial could include the environmental, societal, and health benefits of switching to an active mode of transportation (Ahmed, Rose, \& Jakob, 2013; The Government of Western Australia, 2013). Some societal and environmental benefits can include a reduction in energy use, air pollution, noise pollution, and less road congestion (Martens, 2007). Providing a range of incentives to employees has the potential to create a meaningful transition to cycling as a utilitarian mode of transportation.

The literature surrounding secure bicycle parking has a strong focus on bike-and-ride, or the integration of cycling and public transportation (Martens, 2004; Pucher \& Buehler, 2009; Rietveld, 2000). This information includes many important parallels that can be applied to end-of-trip facilities. For high demand areas it is not feasible to take a bicycle onto the transit system during peak hours (Ahmed, Rose, \& Jakob, 2013). This creates a scenario in favour of the implementation of secure long-term parking in conjunction with short-term unsecure spots. Providing both alternatives gives commuters an option of available facilities to facilitate a range of needs and preferences (Hossain, Botma, Vandebona, \& Kiyota, 2003). Paid parking ultimately gets less utilization in comparison with the free parking, but secure parking is invaluable for attracting a certain subsection of the North American population. The implementation of secure bicycle parking leads to an increase in user satisfaction and use levels (Martens, 2007). Many downtown work environments have space at a premium, thus bringing bicycles into the office would be prohibitively difficult and costly. This furthers 
the case for the provision of secure bicycle parking facilities for the employees in the associated buildings. Secure parking would grant employees a location to store their bicycle safely during the workday, while unsecure bicycle parking near building entrances would promote the use of bicycles for short-term trips to the building.

Weather is a major determining factor in individual's propensity to cycle to work (Wardman, Tight, \& Page, 2007). Toronto experiences cold weather in the winter with temperatures falling to an average low of minus 7 degrees Celsius in January. In Toronto individuals can typically ride comfortably from March (average low of minus 2C) to November (average low of 3C) (World Weather Online, 2015). The inclusion of secure bicycle parking and associated amenities can further facilitate cycling during the winter months, and other inclement weather at other times of the year (Wardman, Tight, \& Page, 2007; Ahmed, Rose, \& Jakob, 2013). Providing heated covered bicycle parking protects the bicycle from the elements during the day, lockers supply convenient storage for winter gear and storage for work clothing, and showers afford commuters the ability to clean up before commencing their workday (something particularly important when cycle routes are wet or slushy). These endof-trip facilities work in conjunction with on street cycling infrastructure in the promotion of year round cycling. This ancillary infrastructure maintenance includes maintaining the cycle lanes clear of ice and snow.

Costs of implementing and managing a secure parking facility are also of upmost importance for building managers to understand, to allow a transparent process of implementation. Standalone facilities such as The McDonald's Center in Chicago and Union Station Bicycle Station in Toronto will ultimately have greater capital costs and operating costs then a facility placed within an existing building for a set group of individuals (City of Chicago, 2014; City of Toronto, 2014). Both of the mentioned facilities are in independent structures and any member of the public can pay the user fee to be granted access. In San Francisco the capital cost for a staffed bicycle parking facility range between $\$ 3.6$ million to $\$ 15$ million, with an operating cost between $\$ 360,000$ and $\$ 600,000$ per year (San Francisco County Transportation Authority, 2013). This cost is in contrast with an unstaffed parking facility in San Francisco that has a capital cost of $\$ 2.5$ million, with an operating cost of $\$ 10,000$ per year (San Francisco County Transportation Authority, 2013). Thus a staffed facility represents a significant financial expenditure when compared with an unstaffed facility. 
Office buildings would be best suited for an unstaffed facility that would be built within the existing structure. Since these facilities consistently have restricted access it will be substantially cheaper to construct and operate. This operation model would be more in line with the facility constructed at Concordia University in Montreal that is unstaffed and built for students, staff and professors of the University (Transport Canada, 2010; Concordia University , 2014). The Concordia facility had a capital cost of $\$ 7,800$ and has a capacity for 86 bicycles. The operating cost of the Concordia facility is 300 dollars a year, drastically lower than the estimated 100,000 dollars needed to run the station in Chicago's Millennium Park with a capacity of 300 spots (Transport Canada, 2010; City of Chicago, 2014). This range of capital and operating costs exemplifies the range of options available for office buildings, and illustrates that implementation of a secure facility does not necessary have to represent a large financial burden. 


\section{SUPPORTING POLICY DOCUMENTS}

\section{Toronto's Official Plan}

Toronto's Official Plan (2010) specifically recommends the inclusion of specific policies, programs and infrastructure to create a safe and accessible bicycle environment. Toronto's Bike Plan (2001) helped inform the recommendations set forth in the Official Plan. The Bike Plan was set as a 10-year strategy to guide the development of new policies, programs and infrastructure intended to accommodate future bicycle use for everyday transportation and enjoyment (City of Toronto, 2010). Section 2.4 policy 7 of Toronto's Official Plan includes:

a) An expanded bikeway network;

b) Provision of bicycle parking facilities in new developments;

c) Provision of adequate and secure bicycle parking at rapid transit stations; and measures to improve the safety of cyclists through the design and operation of streets and through education and promotion programs.

\section{The Provincial Policy Statement}

At the provincial level the Ontario Government has put forth the Provincial Policy Statement that provides policy direction on matters of provincial interest related to land use planning and development (Ministry of Municipal Affairs and Housing , 2014). The report highlights the importance of efficient development patterns that allow for a range of feasible transportation options, with transportation choices that increase the use of active transportation and public transit in preference to other modes of transportation. The Provincial Policy Statement outlines that settlement areas shall be based on densities and a mix of uses that, among other benefits, support active transportation. Settlements will be promoted that reduce the length and number of vehicle trips and support current and future use of public transit and active transportation (Ministry of Municipal Affairs and Housing , 2014). This policy document extends into energy conservation, air quality, and climate change. The reasoning behind this report follows that increasing active transportation through effective land use planning can help achieve the provinces target of enhancing the quality of life for all Ontarians. 


\section{Zoning Regulations}

Incentives and changing market conditions can help create a shift towards a greater cycling modal share, but it is also imperative to add regulations by way of city by-laws. This creates uniformity across organizations and ensures adequate facilities are provided in all affected new developments. The City of Toronto in its Zoning By-law has Chapter 230: Bicycle Parking Space Regulations, which dictates the bicycle parking needed for a range of different building types and sizes (City of Toronto, 2013). Other cities that include secure parking include the City of Vancouver with its Parking By-law outlining Off-street Bicycle Space Regulations in Section 6, and New York City that adopted a Bicycle Parking Text Amendment in April of 2009 that addresses the provision of secure bicycle parking facilities (NYC Department of City Planning, 2008; City of Vancover, 2012). For each of these zoning regulations there was a similar focus on commercial regulations for bicycle parking, in addition to other forms of bicycle parking.

The Toronto Zoning By-law divides the City into two zones: Bicycle Zone 1 and Bicycle Zone 2, each with its own parking regulations. Bicycle Zone 1 encompasses an area bounded by the Humber River on the west, Lawrence Ave. on the north, Victoria Park Ave. on the east, and Lake Ontario on the South. Bicycle Zone 2 includes all areas in the City outside of Zone 1 (City of Toronto, 2013). This in part recognizes different densities and transit facilities that impact transportation modal share in different areas of the City, with areas closer to downtown being more amenable to cycling. The By-law highlights the minimum dimensions for different bicycle parking space allotments, creating a framework for the provision of bicycle parking in a uniform effective manner. These spaces are then zoned based on a ratio for every 100 square meters of interior floor area depending on the Bicycle Zone (City of Toronto, 2013). To provide incentives for the implementation the By-law permits the official gross floor area of a building to be reduced by the area used for, among other things, bicycle parking spaces and the associated amenities. These amenities for commercial office towers involve shower and change facilities that are provided for each gender based on the number of bicycle parking spaces required (City of Toronto, 2013).

Before 2013 the City of Toronto had zoning that differed based on the pre amalgamated city. North York, Scarborough, and the South District (former City of Toronto) all had their own bicycle parking zoning regulations. Given the geographic scope of this paper the previous South District zoning by-law carries the most relevance. By-law 438-86, Section 
4 (13) enacted in 1993 governed the quantity of bicycle parking spaces required, and the associated shower and change facilities. Updated in 1997 commercial developments were required to provide 6 bicycle parking spaces, or 1 space for every 1,250 square metres of net floor area. This regulation dictated a ratio of occupant to visitor parking of $80 \%$ to $20 \%$ respectively, with the occupant parking needing to be either a bicycle locker or secure room (Cycling Infrastructure and Programs, 2008). This is in contrast with 0.2 secure spots per 100 square meters of interior floor area required in the 2013 By-law for Bicycle Zone 1 (City of Toronto, 2013). This would equate to 2.5 spots per 1,250 square meters, effectively more than doubling the required space over the 1993 requirements, with a separate provision for unsecure public bicycle parking.

Additionally Chapter 200 of Toronto's zoning Bylaw has a clause pertaining to bicycle parking in 200.5.10 under heading 12. This allows vehicle parking to be reduced while bicycle parking is increased in Policy Area one, which encompasses the Downtown. The vehicle parking may be reduced at a rate of 1 vehicle parking space for each 5 bicycle parking spaces provided in excess of the minimum number of bicycle parking spaces highlighted in Chapter 230. The reduction of vehicle parking must also not be greater than $20 \%$ of the total minimum vehicle parking spaces required (City of Toronto, 2013). This provides developers with the opportunity the measure the feasibility of different parking allocations.

New York and Vancouver, representing two other North American cities with secure bicycle parking zoning regulations, operate in a different political, environmental, and economic landscape compared with Toronto. But zoning practices in these cities represent an indirect comparison of regions in North America that have implemented bicycle parking regulations into their zoning by-laws. The direction other cities have taken can reinforce existing principles in Toronto, introduce invaluable information, and stimulate the political will to pursue changes to the status quo. For this reason it will be valuable for future research to expand on this Toronto specific study and examine the implementation of secure bicycle parking in other major North American cities.

Zoning requirements for secure end-of-trip facilities in North America illustrate a recent shift in land use practices to accommodate healthy forms of transportation. These requirements are an important initiative towards accommodating bicycling as a utilitarian form of transportation, and highlight active transportation as a city priority. The limit of 
these regulations is they apply to only new land development and major renovations; buildings built prior to the zoning amendment are not bound by the same requirements. This creates a limitation as many office towers were built prior to the zoning amendments, leaving the building managers' in-charge of the end-of-trip facilities that are made available. 


\section{METHODOLOGY}

The current literature and research on the secure bicycle parking lacks meaningful primary data on existing facilities in downtown Toronto. The zoning by-laws pertaining to secure facilities have only recently been implemented, leaving a large number of office towers unaffected. This created a research opportunity to examine the existing inventory of secure bicycle parking facilities in office buildings in downtown Toronto, highlighting strengths and weaknesses, and opportunities for future growth.

Due to resource and time constraints the scope and project deliverables had to be narrowed. The office inventory in downtown Toronto is comprised of over 72 million square feet, and downtown has seen an increase in 1.6 million square feet of office space in 2014 . This inventory accounts for 109 office buildings in the Financial Core, with 491 total office buildings in the downtown (Arnoldi, West, \& Gilligan, 2014). This creates a substantial sample size that would not fit within the projects timelines. Additionally, creating a random sample of these buildings would not yield an optimal result as not only are buildings by their nature idiosyncratic, but many buildings predate the current bicycle parking zoning requirements and are without any facilities. Since the deliverable for this project is focused on providing recommendations for the implementation of secure parking facilities, the most valuable data will be the current facilities and how they operate. Thus this project is centred on a case analysis of current end-of-trip facilities at office towers.

The buildings were chosen on a macro level through several prominent building management companies, and then were contacted on an individual basis to assess whether they fit into the project parameters. This also provided the management companies with my research goals allowing them, in some cases, to put me in contact with individuals with greater knowledge of their end-of-trip facilities. The sample size of 13 office towers was entirely self-generated based on the response rates and ability to answer the survey questions. This included a range of buildings from new buildings adhering to zoning requirements, and older buildings with and without bicycle parking. The sample size, while not exhaustive, provided a reasonable cross section of the downtown market so as to effectively formulate a list of recommendations. See below for a map of the studied office towers (City of Toronto, 2015). This sample group created the necessary structure to examine secure bicycle parking facilities, or lack thereof, on a case-by-case basis within the study area. 
The data collected involved in-person examination of end-of-trip facilities to assess their individual characteristics and environment, as well as interviewing individuals associated with the management or operation of the secure bicycle parking facility to gather data on its current and anticipated future use, associated amenities located elsewhere, and demand management techniques. The questions addressed were purposely kept nonintrusive and short to create a more accessible survey that would not be overly time or resource consuming (See Appendix A for the survey questions).

Processing the collected data was done on a per case basis. The facilities provided by the different buildings were variable and were dependent on the sites' individual characteristics. Assessing each building separately allowed site-specific characteristics to more effectively address the research question. Older buildings, predating bicycle-parking zoning requirements that provided secure bicycle parking had a variety of implementation and operation models, creating a unique layout not governed by the current zoning by-laws. By contrast the new office buildings governed by the current zoning by-laws had bicycle parking, but the implementation layout varied. Ultimately this method of individual assessment allowed each separate facility to work synergistically to inform a range of recommendations for future policy directions.

Assessing the existing end-of-trip facilities in downtown Toronto on a per case basis enabled the project to elicit enough data to effectively produce a list of recommendations. The current trend towards healthy forms of transportation is still in its infancy in North America, necessitating the urban environmental changes that will promote the future implementation of secure end-of-trip facilities. New office towers will be required to provide a certain level of secure bicycle parking, and existing office towers that predate bicycle parking zoning regulations may be driven by increases in demand to provide end-of-trip facilities or simply upgrade their existing facilities. For this reason this process of examining existing end-oftrip facilities in office towers is an iterative process. As new facilities come on line, and existing ones are upgraded, the need to expand research on this topic will be important. In addition, with several hundred office towers located in downtown Toronto it was beyond the resource and time constraints of this paper to do a comprehensive inventory, providing another avenue for future research efforts. The recommendations in this paper are thus designed to provide a basis to guide future evaluation and documentation of facilities not present in this paper. 


\section{Office Buildings Researched}

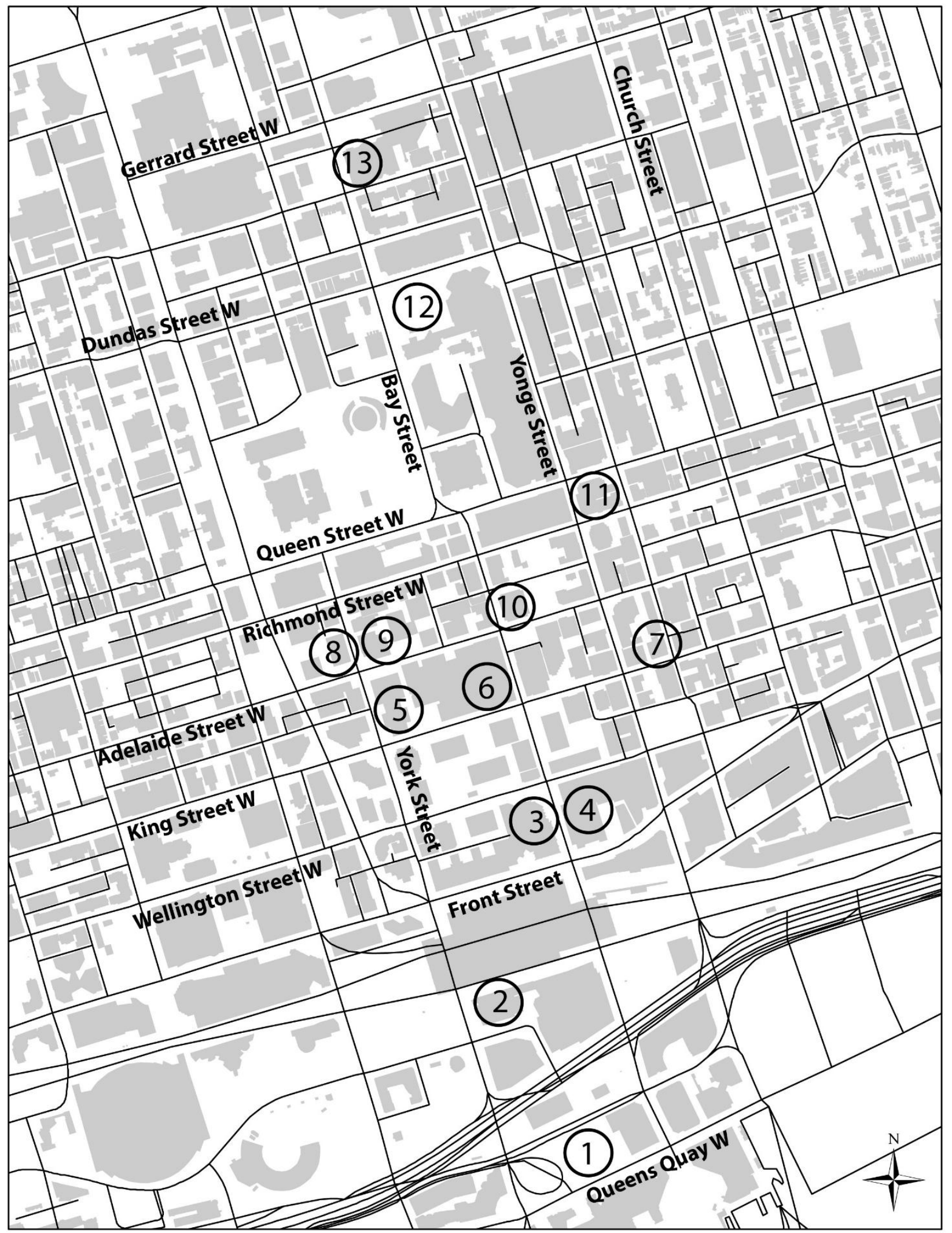




\section{RESULTS}

Creating a case analysis of secure bicycle parking in downtown Toronto office buildings required a sample size with a diverse range of buildings. As such, included in this analysis are buildings that are geographically spread out in the study area, with a range of different construction and renovation dates, and with significantly varying building size. The variety of buildings selected enabled a more comprehensive process upon which to base the recommendations, and allowed for a series of recommendations that are cognisant of the current diverse office building market in Toronto.

\section{1) 88 Queens Quay West}

This office tower is a part of the RBC Waterpark Place operated by Oxford Properties, which is a new development on Toronto's Waterfront. Its construction was finished in 2014 and represents the first LEED Platinum CS office tower. 88 Queens Quay West is 30-storeys and is comprised of $867,686 \mathrm{SF}$ (square feet). Given its recent construction the building has integrated numerous state of the art environmental features (Oxford Properties Group, 2015). Included in this is a secure bicycle parking facility.

The secure bicycle parking is provided via a separate bicycle room with capacity for 170 bicycles. In addition there is visitor bicycle storage for 122 bicycles. These facilities are located on the first level of the parking garage, with a separate entrance. In addition there is a space to store bicycle locks, and a men's and women's change room. Each change room includes 46 lockers and 13 showers. Tenants of the building can have their pass card activated for the bike room and amenities. Access to the facility is provided free of charge to tenants, in comparison with a cost $\$ 220$ per month for unreserved and $\$ 355$ per month for reserved parking for automobiles.

The entrance is a staircase that leads from outside directly into the bicycle room. The stairway has a wheel channel to accommodate walking a bicycle up and down. This eliminates vehicle and bicycle interactions in the parking garage, enhancing the safety. In addition the facility is monitored via security cameras.

Demand management is done through quarterly audits to ensure correct use of the facility. This includes ensuring that bicycles are not "abandoned" in the room and non-bike related items are not being stored in the facility. With the size of the facility and its relatively 
new construction date Oxford has not encountered any capacity constraints. The other towers that make up part of RBC Waterpark Place will each have separate bicycle rooms upon final completion.

\section{2) 25 York Street}

At a height of 30-storeys and 785,000 SF, the Telus Tower, operated by Menkes, is a prominent office tower immediately south of Union Station. Built in 2010 it is a LEED Gold AAA certified building, with connections to the PATH System. The building has incorporated a sustainability vision into its design, which includes a state of the art secure

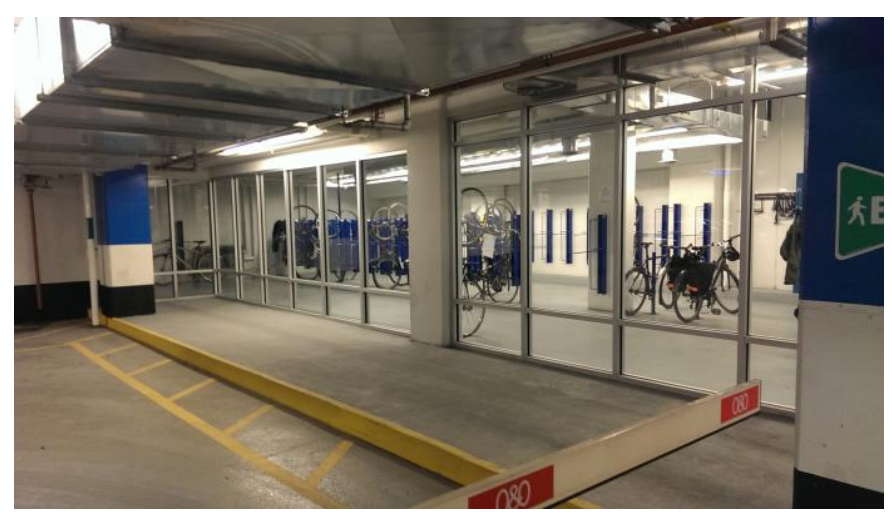

Figure 3: Secure bicycle room 25 York Street bicycle parking facility (Menkes, 2015). The facility is only accessible via a building pass card, which all tenants have for general building access. This limits access to the facility to employees of 25 York Street enhancing its security. The room also has security cameras that are monitored, further deterring criminal activity. The bike room is located on P1 of the parking garage with close proximity to the entrance ramp, limiting the interactions between bicycles and vehicles in the garage. The bike room has a capacity of 68 spaces with users also having access to 38 personal lockers, an area to store their lock and two change rooms equipped with washrooms and showers.

To date the facility has not encountered any capacity constraints, with the supply of secure parking meeting the existing demand. To continue to ensure the existing facility meets the demand the management team has the rules and regulations posted in the room (such as no long-term storage of bicycles, and no storage of non-bicycle related items), which helps to ensure the correct usage of the space. Menkes also conducts quarterly audits of the room to remove any "abandoned" bikes or items. Tenants have access to the secure bicycle parking room on a first come first serve basis, which given its current state of available spaces has not become an issue. To supplement the secure bike room 25 York Street also has additional bike racks, both indoor and outdoor, that can be utilized by the public. The indoor unsecure facilities are located on the P1 level as well and offer the security of surveillance and controlled access compared with the unsecure bicycle parking outside. 
Tenants of the building can get their pass cards activated for the bike room at no charge, removing a cost barrier for employees to utilize the facility. To park a vehicle unreserved costs $\$ 335$ per month, with reserved costing $\$ 495$ per month. Providing free access to the bike room while charging for tenant parking helps to incentivize the use of active transportation.

\section{3) Royal Bank Plaza}

Owned and operated by Oxford Properties the Royal Bank Plaza consists of two office towers, the North Tower and the South Towers. The South Tower is 41-storeys and the North Tower is $26^{-}$ storeys, with a combined square footage of 977,960 . The building was originally constructed in the late 1970s, before there was bicycle-parking zoning in

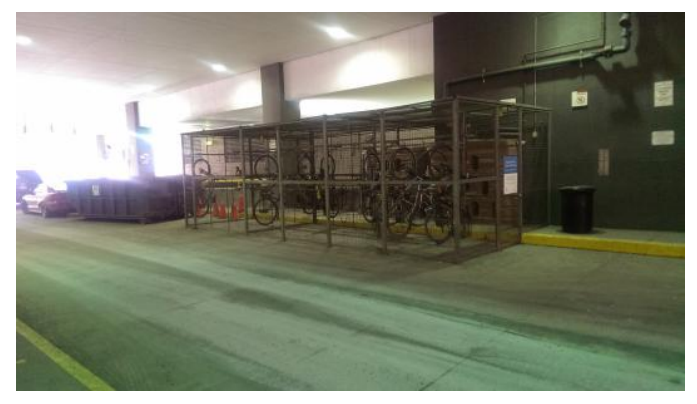

Figure 4: Outdoor secure bicycle cage Royal Bank Plaza Toronto and management companies did not include them in the floor plans of office towers. Both towers underwent their most recent renovation in 2008, pushing the building towards its LEEDS-EB Gold Certification in 2010 (Oxford Properties Group, 2015). This award recognizes the many sustainable strategies incorporated into the office building, including its secure bicycle cage.

The bicycle cage is located on the east side of the Royal Bank Plaza, between the office building and the Fairmont hotel. The cage is located outside next to the shipping and receiving area, and has approximately room for 30 bicycles. The facility does not have the issue of conflicting bicycle and automobile right of way in the parking garage due to its location outside.

This area is protected from the elements in a ground level laneway connecting with the shipping and receiving area. From a security standpoint the facility is only accessible by tenants of the associated building, and the area is monitored via several security cameras.

Tenants of the buildings have access to the bicycle cage free of charge. This is in comparison with $\$ 477$ per month for reserved parking, $\$ 372.35$ per month for unreserved on P1, and $\$ 344.50$ per month for unreserved on P2 and P3. 


\section{4) Brookfield Place}

Operated by Brookfield Office Properties the Bay Wellington Tower has a LEEDs Gold certification for its Operation and Maintenance program. It is located in the heart of the financial district immediately north east of Union Station at 181 Bay Street. The Bay Wellington Tower, built in 1992, is 47-storeys, and has 1.297 million SF of office space (Brookfield, 2015).

The Bay Wellington Tower does offer secure bicycle parking to its tenants by way of a bicycle cage. The secure bicycle cage has capacity for approximately 70 bicycles, with additional unsecure parking located in the same vicinity. Located outside of the cage is a secured bicycle repair stand, a tire inflation station, and coin operated lockers for day storage.

The cage is located in close proximity to the entrance ramp in the first level of the parking garage. With the parking management office and the courier mailroom directly in front of the facility the area gets a high volume of traffic adding additional safety in addition to the monitored security cameras.

To assess the demand for the facility the parking management company, Standard Parking of Canada Ltd, utilizes the Smart Commute survey and tenant surveys. These surveys when paired with the number of applications for the secure bicycle parking allow for a more accurate assessment of current and future needs. The bicycle cage was expanded in 2014 to include an additional 20 spots due to increases in demand.

Tenant access to the secure parking is done on a yearly basis at a cost of $\$ 75$ per year. This cost is in comparison with a monthly vehicle parking pass equating to $\$ 440.42$. The bicycle cage represents a cost effective alternative to driving, encouraging the shift towards more sustainable transportation.

\section{5) Exchange Tower}

The exchange tower is home to the Toronto Stock Exchange, making it a primary focal point of Toronto's financial services industry. The building is 36 floors comprising of 963,000 SF of office space. The Exchange tower is a certified green building with a Gold level of certification in the LEED Existing Building: Operation and Maintenance program (Brookfield, 2015). A factor is this certification is its attached secure bicycle parking facility. 
The Exchange Tower offers both secure and unsecure parking on the A1 level of the parking garage. This includes 60 public spots and 41 secure spots located in a secure bike room. The secure facility is located in a well illuminated area of the parking garage, within close proximity of the entrance ramp. Only tenants of the building have access to the secure room. The parking garage is staffed and the area is monitored by several security cameras.

Tenants have access to the facility through a yearly bike lottery program, which tends to get around 60 entrants each year for the secure facility. To manage increases in demand Brookfield has placed and continues to place additional unsecure racks in the parking garage. These racks still offer security and weather benefits in contrast to outdoor public racks, and are more easily integrated into the existing parking garage in comparison to secure facilities. Those granted access have their building pass cards activated for the room at a charge of $\$ 60$ dollars for the summer and $\$ 100$ dollars for annual parking. This is in comparison with $\$ 680$ for reserved parking and $\$ 436$ for unreserved per month.

\section{6) First Canadian Place}

At 72-storeys First Canadian Place is the tallest office building in Canada. It is located in Toronto's Financial District at 100 King Street West. The tower was built in 1975 and has over 2.3 million SF of office space. First Canadian Place is a certified green building with a Gold level of certification in the LEED Existing Building: Operations and Maintenance program (Brookfield, 2015). Part of this environmental design is the inclusion of secure bicycle parking.

First Canadian Place has both secure and unsecure parking on the first level of its parking garage. There are five floor mounted racks with capacity for 20 bicycles and 32 vertical mounts located directly in the parking garage, and 53 secured bicycle spots located in a separate room. The secure room is only accessible to tenants of the building. Alongside the secure parking the room provides bicycle repair equipment, a bike pump, lockers, and seating. The parking garage is well illuminated and is monitored by security cameras, enhancing the safety of both the secure and unsecure bicycle parking facilities. In addition the secure facilities location close to the entrance ramp limits the interaction between bicycles and automobiles.

The secure bicycle room has yet to experience capacity constraints, but Brookfield has noticed a rise in demand in the past several years. To manage the demand of the facility 
Brookfield regularly monitors the percentage occupancy, the building demographic, and the demand use. This allows the management team to anticipate changing shifts in the cycling modal share and plan accordingly. Tenants granted access to the secure bicycle parking will get their building pass cards activated for the room. The secure room costs $\$ 60$ for the summer and $\$ 100$ annually. This is in comparison to a cost of $\$ 436$ per month for unreserved parking.

\section{7) 18 King Street East}

18 King Street East, located just east of Yonge, is owned and operated by Dream Office REIT. The office tower was built in 1968 with its last renovation in 1989, predating secure bicycle parking zoning regulations in Toronto. It is 18-storeys totalling 232,036 SF, and has two levels of underground parking (Dream Office REIT, 2015).

Similar to 150 York Street, 18 King Street East offers a bicycle cage to its tenants. With the building's construction happening before the implementation of bicycle parking zoning this cage was retrofitted onto the property. The cage has the capacity of 8 individual bicycle racks and is located at the rear of the building outside of the parking garage. The cage has a pin code access that tenants can get access to that is changed at regular intervals to increase the safety. There are no bicycle amenities other than the cage.

Demand for the facility is assessed by monthly visits to measure usage, and for tenants with access it is done on a first come first serve basis. Access to the cage is free for tenants, which compares with the $\$ 335$ dollars a month necessary to park an automobile.

\section{8) Adelaide Place}

Owned and operated by Dream Office REIT, 150 York Street is a Class A building located in the financial core. The building was constructed in 1982, predating the current and previous zoning regulations for secure bicycle parking. The office building is 20-storeys totalling 356,666 SF, and it has 3 levels of underground parking (Dream Office REIT, 2015).

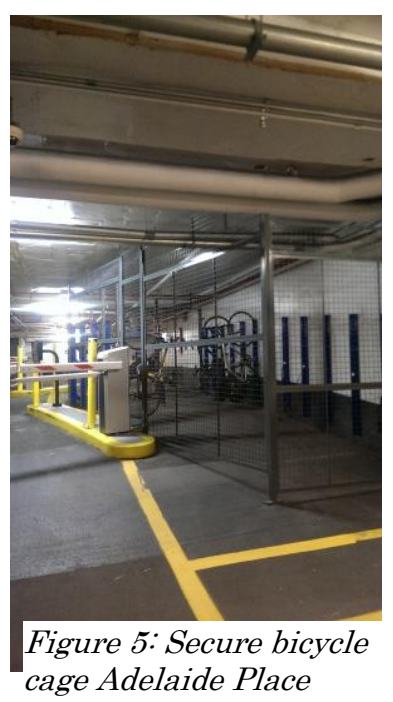

150 York has a bicycle cage located in close proximity to the entrance ramp in $\mathrm{P} 1$. The bicycle cage has 16 individual bicycle racks, with unsecure parking located on the same level in the parking garage. Both the cage and unsecure parking benefit from weather protection, 
security cameras, and being located in a staffed parking garage. To further enhance the security the bicycle cage was renovated in 2008 to reach the ceiling, due to an individual scaling the cage and removing a bicycle.

With a construction date prior to the mentioned bicycle parking zoning regulations this parking garage was retrofitted with a bicycle cage after the initial construction. This creates limited space for expansion due to its prime location immediately at the entrance to the parking garage. The bicycle cage is in a conflicting right of way with vehicles, limiting the expansion potential of the facility.

Demand management techniques include a monthly inspection of the cage to monitor its usage. Tenants have to pay a 25 dollar deposit to get the key to the facility, but get the deposit back in full when they return the key. The Site Manager for Impark in charge of the bicycle parking has noticed that the majority of users are fair weather cyclists and a large number of people will get the key and then fail to use the facility. For tenants who have access to the facility it is available on a first come first serve basis. This facility benefits from vehicle parking provided to tenants at 300 dollars a spot, creating a financial disincentive for driving to work.

\section{9) Richmond Adelaide Centre}

Owned and operated by Oxford Properties the Richmond Adelaide Centre is a 1.6 million square foot cluster of office buildings located in Toronto's financial district. The office buildings include the newly renovated 111 Richmond Street West Class A LEED Gold-CS tower and 130 Adelaide Street West that recently underwent a $\$ 40$ million renovation of its lobby and elevators (Oxford Properties Group , 2015). This complex is connected with the PATH system and is in close proximity to the pilot segregated bike lanes west of University on Adelaide Street West and Richmond Street West.

The Richmond Adelaide Centre provides secure bicycle parking by way of a bicycle cage for the tenants of the building. At the bottom of the ramp to the parking lot off of York Street there is a cage with 35 bicycle racks for tenants and unsecure public access racks immediately outside the facility. Google is one of the tenants of the building and they offer an additional 85 spots for their employees. The cost of the bicycle cage is free for tenants, in comparison with $\$ 382$ per month to park an automobile. As with other buildings, the cost to park a car provides an incentive towards use of alternative methods of transportation. 
With both cages and the unsecure bicycle racks in the garage the parking management has never reached capacity concerns. Tenants interested in utilizing the facility are given a key and the cage is managed on a first come first serve basis. The public access racks will fill up during peak times in the summer and the cage will experience high demand as well. The parking authority also mentioned an increase in year round cycling, and that demand at all times of the year has been steadily rising.

Providing separate facilities for specific tenants illustrates an increase in demand for secure bicycle parking and an understanding that providing such accommodations can attract certain organizations. This model is similar to an office building at 901 King Street West that provides a general access bicycle cage, and a separate tenant specific cage. This is a relatively new model and represents an interesting method of enticing tenants or getting tenants to cover costs of implementation. This helps remove a cost barrier associated with the implementation of secure bicycle parking.

\section{0) Bay Adelaide Centre}

Built in 2009 the Bay Adelaide Centre West (333 Bay Street) was Toronto's first LEED Certified Core and Shell Gold high-rise office building. Owned and operated by Brookfield Office Properties, it is connected with the PATH System and represents a new "AAA" class of office tower. The building is 51-storeys with 1.155 million SF of office space, 37,000 SF of retail, and 382,000 SF of parking (Brookfield, 2015). The Bay Adelaide Centre has a planned east tower with a scheduled completion of 2015 to early 2016 , and a north tower, for which a construction date has not yet been announced.

The secure bicycle parking is located in a separate room in the

P1 level of the parking garage. The facility has capacity for 150

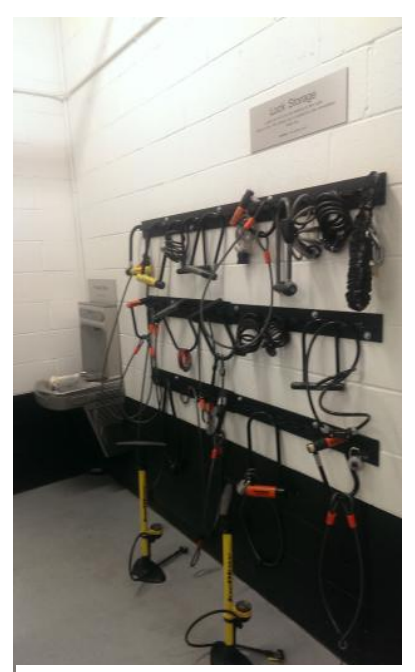

Figure 6: Bicycle lock storage wall Bay Adelaide Centre bicycles and has 28 full size lockers. Amenities include a bicycle lock storage rack (to keep them off actual bike racks and provide tenants with the option to not carry a heavy lock on their commute), bicycle tools, and access to a separate area with 8 executive change facilities with showers and washrooms. The facility will be further expanded with the construction of the east tower to facilitate the anticipated increase in demand. 
To manage the usage of the facility Brookfield leases the space to tenants based on their square footage of office space. In addition they conduct occasional audits to ensure the facility is being utilized properly. Although with such a large supply of bicycle parking spots within the bike room Brookfield has never reached capacity in the room. This has led to a more relaxed allotment of space per tenant.

The parking garage was built with this facility in mind, leaving a wide berth on the entrance ramp and another completely separate bicycle and pedestrian entrance to the facility. The facility itself is in a well-lit area and closely monitored via security cameras.

The bike room is currently free for tenants with access granted through their building pass cards. Management at Brookfield is currently assessing whether to levy a user charge in the future. This is in comparison with a monthly vehicle pass costing $\$ 400$, incentivizing non-automobile forms of transportation.

\section{1) One Queen Street East}

One Queen Street East is comprised of two buildings of different vintages. 20 Richmond Street East at 7-storeys was built in 1896, with One Queen Street East, totalling 27-storeys, added as an addition in 1991 (20 VIC Management Inc., 2015). This building is directly connected to the PATH System and is centrally located near the Toronto Eaton Centre. With One Queen Street East opening in 1991 it did not have to adhere to any secure bicycle parking zoning regulations, leading to such facilities not being included in the initial construction plan.

The office building does provide a range of bicycle facilities for its tenants. In the parking garage there are racks that can hold approximately 60 bicycles. These racks are in the first level of the parking garage, with access to the parking garage requiring tenant access. The parking garage is not public meaning only those with building pass cards can access the area. In addition there is a separate bicycle room, secured by a lock that can fit approximately six bicycles that is used exclusively by one tenant. The parking garage does not include any additional bicycling amenities, with specific tenants having access to showers and change rooms on their floors. Both the racks and secure room are offered free of charge.

From a security perspective the regular racks, while out in the open, are secured by a tenant access parking garage door and the area is monitored by security cameras. The secure room for one tenant distributes keys to those interested, limiting the access to a specific group 
of individuals. This also allows the demand for the secure room to be monitored to ensure it does not exceed capacity.

\section{2) Toronto Eaton Centre Towers}

The Toronto Eaton Centre Towers are comprised of 20 Queen Street West, 1 Dundas Street

West, 250 Yonge Street, and 220 Yonge Street. 20 Queen Street West, built in 1979, has 36 office floors and a rentable area of 674,199 SF; 1 Dundas Street West, built in 1977, has 29 office floors and a rentable area of 450,354 SF; 250 Yonge Street, built in 1991, has 35 office floors and a rentable area of 716,432 SF;

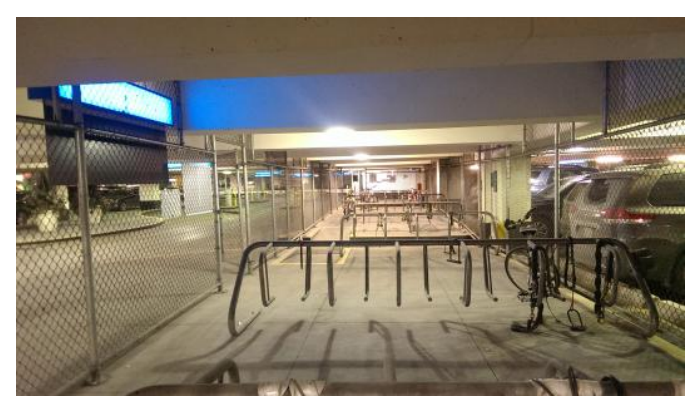

Figure 7: Traditional Bicycle Rack Toronto Eaton Centre and 220 Yonge Street, built in 1977, has two office floors and a rentable area of 55,195 SF. These towers are all operated by Cadillac Fairview, which has implemented a Green at Work program promoting environmentally friendly initiatives (The Cadillac Fairview Corporation Limited, 2011).

Each of these buildings predates bicycle-zoning regulations in the City of Toronto, making the provision of secure parking the exclusive responsibility of the building management company. Cadillac Fairview, recognizing this shift in transportation preference, retrofitted its parking garage at Bay and Dundas Street to include a bicycle cage. Included in this bicycle cage is room for approximately 72 bikes, with the inclusion of 4 separate secured smaller cages. The bicycle cage utilizes a more traditional multi bike rack fixed to the floor. This cage is left unlocked granting free access to any member of the public, with the exception of the separate secured cages.

This cage lacks the security of the other facilities visited due to its intended user base extending beyond the tenants of the office towers. The cage is in a well-lit area and is located in close proximity to a staffed parking booth and the parking management office. The area also has several monitored security cameras further enhancing the security of the area.

\section{3) 655 Bay Street}

655 Bay Street is located in the Downtown North submarket and is operated by Dream Office REIT. It is a class A office building comprising 18-storeys and 308,431 SF, and was built in 1991 (Dream Office REIT, 2015). This building predates the secure bicycle parking 
zoning regulations in Toronto. The property does include public bike racks in view of security cameras and tenant accessible shower facilities. These shower facilities are located within the building's exercise room, which tenants can pay an annual rate to use.

An interview with the property manager did highlight that there has been a move towards more active forms of transportation as vehicle and transit costs rise. Dream Office has retrofitted several other older office buildings with bicycle cages but cost and space remain primary barriers to implementing it on a larger scale. Vehicle parking passes cost $\$ 250$ per month for tenants.

\section{Types of Bicycle Racks Used}

Secure bicycle parking on office property in Downtown Toronto is situated on very valuable land. For this reason it is important to utilize a bicycle rack that utilizes the allotted space most effectively. A majority of the 13 facilities visited provided upright racks, where the bicycle was stored in a vertical position. This allows for more bicycles to be stored per square foot then tradition horizontal racks. Another variation implemented by 88 Queens Quay West and the Union Station Bicycle Station is a double decker rack. The upper rack runs on tracks and lowers for an individual to place a bicycle then slides back up above the rack located on the ground. This allows for a

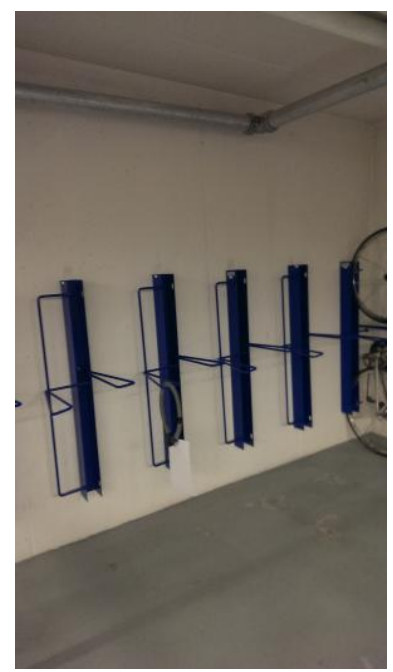

Figure 8: Upright Bicycle Racks 25 York Street high density of bicycles to be parked effectively, but requires a higher ceiling then the vertical racks. More traditional fixed multi bicycle racks where provided at the Toronto Eaton Centre bicycle cage and the Bay Adelaide Centre had both traditional and vertical bicycle racks. These racks are not as permanent as the other two, the vertical racks require bolting to the wall or floor and the double stacked racks require extensive installation. The more traditional racks therefore can provide a short-term bicycle parking rack, and if demand for the associated facility increases drastically it can be exchanged with a more space efficient design.

\section{General Findings}

In conducting the research on each facility there were several findings that held true for several facilities. For instance the building representatives for all 13 office towers mentioned an increase in demand for secure bicycle parking over the past decade and 
highlighted that they anticipated demand to continue to rise. This was an important result as it will shape the provision of secure bicycle parking in office towers for the foreseeable future. This information will help different interest groups in formulating a strategy to meet this increase in demand.

To better understand and plan for an increase in demand it is important to understand the current and previous zoning regulations in comparison with each of the buildings studied. Since most of the buildings were built prior to 1993 they did not have secure bicycle parking zoning regulations to follow. Only three of the researched office towers were built after 1993, with only one built after 2013. The chart below provides a breakdown of the buildings showing their completion year, total square meters of office space, current provision of secure bicycle parking, and what they would have otherwise had to provide under both the 1993 and 2013 zoning by-law. The 1993 zoning only requires 80\% of the total space to be secure bicycle parking so totals in that category could be reduced, with the excess devoted to unsecure parking. This is important as it illustrates that the planning regulations are adapting to a changing land use and transportation environment.

Another commonality between several facilities were the barriers associated with implementation and expansion of secure bicycle parking facilities. The two primary barriers, explicitly mentioned by a majority of building representatives, included cost of construction and allotment of the required space. The building representatives that mentioned these two barriers included office towers that had retrofitted their building with secure bicycle parking, these include: Adelaide Place, the Richmond Adelaide Centre, 655 Bay Street, 18 King Street East, and Brookfield Place. Buildings with adequate existing capacity to handle the demand did not share these barriers, these buildings include: 25 York Street, 88 Queens Quay West, the Bay Adelaide Centre, and First Canadian Place. Although these building representatives did not explicitly state these two barriers if demand was to substantially increase it may prove space and cost prohibitive to expand their facilities.

Many of the end-of-trip cycling facilities were offered free of charge, and those with a user charge do not account for the lost parking revenue. Based off the site visits the secure facilities were typically situated on the first level of the parking garages. This provides optimal accessibility as highlighted in the literature, but due to the prime location proves to be in a conflicting right of way (Lefrancois, 2014; Sully, 2006). Implementing or expanding 
facilities in space not previously allotted for bicycle parking encroaches on entrance and exit vehicle lanes and removes paid parking spaces.

A majority of the buildings researched also had some level of LEEDs certification. This is a Leadership in Energy and Environmental Design certification that incorporates many sustainable and environmental variables. This provides their building with public relations benefits, and can possibly lead to financial benefit. While the primary focus is on reducing waste, conserving energy, and decreasing water consumption part of their certification can involve sustainable transportation, creating a vested interest for buildings to provide secure bicycle parking.

A difficulty encountered gathering this research was the low initial response rate. Many emails to different building property managers were left unanswered. The provision of secure bicycle parking to tenants is only a small fraction of the management company's tasks, leading to emails sent to general lines or individuals not directly associated with bicycle parking. Augmenting this survey involved personally visiting the management offices of all the surveyed office buildings regardless of email responses, and supplementing that with telephone calls. This significantly raised the response rate and allowed the gathering of significantly more data for the case analysis.

In addition to the problem of the initial low response rate there were liability concerns with several building operators. This was an expected outcome due to the secure nature of the facilities. This limited the ability to visit certain facilities and take photographs. Several buildings were unwilling to complete the survey for similar liability reasons, with only certain employees able to communicate on behalf of their company. A factor in these liability concerns may rest in the relative lack of credibility of a student researcher. The management companies may have been more receptive to a municipal or higher profile organization collecting the data. 
Site Results Table

\begin{tabular}{|c|c|c|c|c|c|c|c|c|c|c|}
\hline $\begin{array}{l}\text { MAP } \\
\text { ID }\end{array}$ & Building & $\begin{array}{l}\text { Building } \\
\text { opening }\end{array}$ & $\begin{array}{c}\text { Square } \\
\text { Feet } \\
\text { total }\end{array}$ & $\begin{array}{c}\text { Square } \\
\text { Meters } \\
\text { Total }\end{array}$ & $\begin{array}{l}\text { secure } \\
\text { parking } \\
\text { provide } \\
\text { d }\end{array}$ & $\begin{array}{c}\text { Facility } \\
\text { type }\end{array}$ & $\begin{array}{l}\text { Cost for } \\
\text { facility } \\
\text { access }\end{array}$ & $\begin{array}{c}\text { Showers } \\
\text { and } \\
\text { lockers }\end{array}$ & $\begin{array}{c}2013 \\
\text { zoning } \\
\end{array}$ & $\begin{array}{c}1993 \\
\text { zoning } \\
\end{array}$ \\
\hline 1 & $\begin{array}{l}88 \text { Queens } \\
\text { Quay West }\end{array}$ & 2014 & 867,686 & 80610.63 & 170 & $\begin{array}{l}\text { secure } \\
\text { room }\end{array}$ & free & both & 161.22 & 64.49 \\
\hline 2 & $\begin{array}{c}25 \text { York } \\
\text { Street }\end{array}$ & 2010 & 785,000 & 72928.86 & 68 & $\begin{array}{c}\text { secure } \\
\text { room }\end{array}$ & free & both & 145.86 & 58.34 \\
\hline 3 & $\begin{array}{c}\text { Royal Bank } \\
\text { Plaza }\end{array}$ & 1974 & 977,960 & 90855.42 & 30 & $\begin{array}{c}\text { bicycle } \\
\text { cage }\end{array}$ & free & no & 181.71 & 72.68 \\
\hline 4 & $\begin{array}{c}\text { Brookfield } \\
\text { Place }\end{array}$ & 1992 & $1,297,000$ & $\begin{array}{c}120495.1 \\
9\end{array}$ & 70 & $\begin{array}{c}\text { bicycle } \\
\text { cage }\end{array}$ & $\$ 75 /$ year & no & 240.99 & 96.40 \\
\hline 5 & $\begin{array}{c}\text { Exchange } \\
\text { Tower }\end{array}$ & 1981 & 963,000 & 89465.59 & 41 & $\begin{array}{l}\text { secure } \\
\text { room }\end{array}$ & $\begin{array}{c}\$ 60 / \text { summer } \\
\$ 100 / \text { year }\end{array}$ & lockers & 178.93 & 71.57 \\
\hline 6 & $\begin{array}{c}\text { First } \\
\text { Canadian } \\
\text { Place }\end{array}$ & 1975 & $2,379,000$ & $\begin{array}{c}221016.2 \\
4\end{array}$ & 53 & $\begin{array}{l}\text { secure } \\
\text { room }\end{array}$ & $\begin{array}{c}\$ 60 / \text { summer } \\
\$ 100 / \text { year }\end{array}$ & lockers & 442.03 & 176.81 \\
\hline 7 & $\begin{array}{c}18 \text { King } \\
\text { Street East }\end{array}$ & 1968 & 232,036 & 21556.84 & 8 & $\begin{array}{c}\text { bicycle } \\
\text { cage }\end{array}$ & free & no & 43.11 & 17.25 \\
\hline 8 & $\begin{array}{c}\text { Adelaide } \\
\text { Place } \\
\end{array}$ & 1982 & 356,666 & 33135.34 & 16 & $\begin{array}{c}\text { bicycle } \\
\text { cage }\end{array}$ & free & no & 66.27 & 26.51 \\
\hline 9 & $\begin{array}{c}\text { Richmond } \\
\text { Adelaide } \\
\text { Centre } \\
\end{array}$ & 1978 & $1,600,000$ & $\begin{array}{c}148644.8 \\
0 \\
\end{array}$ & 35 & $\begin{array}{c}\text { bicycle } \\
\text { cage }\end{array}$ & free & no & 297.29 & 118.92 \\
\hline 10 & $\begin{array}{c}\text { Bay } \\
\text { Adelaide } \\
\text { Centre }\end{array}$ & 2009 & $1,155,000$ & $\begin{array}{c}107302.9 \\
7\end{array}$ & 150 & $\begin{array}{c}\text { secure } \\
\text { room }\end{array}$ & free & both & 214.61 & 85.84 \\
\hline 11 & $\begin{array}{l}\text { One Queen } \\
\text { Street East }\end{array}$ & 1991 & 400,000 & 37161.20 & 6 & $\begin{array}{l}\text { secure } \\
\text { room }\end{array}$ & free & showers & 74.32 & 29.73 \\
\hline 12 & $\begin{array}{c}\text { Eaton } \\
\text { Centre } \\
\text { Towers } \\
\end{array}$ & $\begin{array}{c}1970 s^{-} \\
1991 \\
\end{array}$ & 1896180 & $\begin{array}{c}176160.8 \\
1 \\
\end{array}$ & 82 & $\begin{array}{c}\text { bicycle } \\
\text { cage }\end{array}$ & free & no & 352.32 & 140.93 \\
\hline 13 & $\begin{array}{c}655 \text { Bay } \\
\text { Street }\end{array}$ & 1991 & 308,431 & 28654.17 & 0 & $\mathrm{n} / \mathrm{a}$ & $\mathrm{n} / \mathrm{a}$ & no & 57.31 & 22.92 \\
\hline
\end{tabular}


This Chart synthesises the individual information for each site, with reference to both the old and new Toronto Bylaw regulations regarding secure bicycle parking. Each building is listed by name and Map ID for the corresponding geographic location on the map located on page 20. The map was based off information taken from the City of Toronto Open Data (City of Toronto, 2015). The year the building opened provides a reference point to base the applicable bylaws. This is only used a base guide since the actual applicable bylaws and exemptions are not provided in this research. Each buildings square footage is included to illustrate the variety of buildings sampled. This number is then transferred to square metres to conform to the Toronto Bylaws. This calculation is then utilized to measure both the 2013 and 1993 bylaws and provide a comparison with the existing secure bicycle parking provided. 


\section{RECOMMENDATIONS}

\section{City Run Facilities}

To create more accessible secure bicycle parking facilities for downtown office buildings there is the opportunity for the City of Toronto to work in collaboration with the different management companies. The City of Toronto currently operates a secure bicycle station at Union Station with 120 bicycle racks. This includes a change facility with a washroom, a bicycle accessories vending machine, and basic bike repair tools. The City has plans to expand the Union Station facility as part of the whole station revitalization process with the addition of another 200 bicycle racks. These stations will be located along York Street, with the current facility at 27 York Street and the planned expansion south of Front Street on York

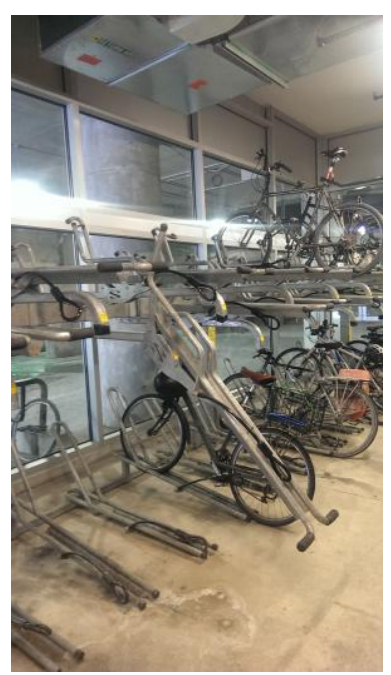

Figure 9: Secure Bicycle Room 27 York Street. In addition there will be a new secure bicycle station at Nathan Phillips square with a planned capacity of 350 bicycles with an anticipated completion date of summer 2015 .

The existing station at 27 York Street carries a user fee for its members to supplement the operational costs of the facility. The costs include a membership fee of $\$ 26.91$ and a monthly, four month and year plan costing $\$ 21.53, \$ 64.57$, and $\$ 129.14$ respectively (City of Toronto, 2014). These costs are higher than all researched office building facilities, but when compared with the costs of parking an automobile this station represents a cost effective alternative. The two new planned facilities will carry similar pricing models.

Both Union Station and Nathan Phillips Square are in close proximity to a large number of downtown office towers, making it conveniently located and easily accessible (Sully, 2006; Lefrancois, 2014). This would create an environment where building tenants could utilize the City secure bicycle parking facilities. For buildings built before the zoning regulations without secure bicycle parking or other buildings without adequate supply, a viable option would be subsiding employees' use of these other facilities. For instance the bicycle cage at the Royal Bank Plaza is over capacity, but with its close proximity to Union Station the bicycle station provides a viable alternative. This would ensure that the tenants 
of the office building would have access to secure bicycle parking, while limiting the burden on the management company.

The two largest barriers expressed by the building representatives for each office management companies were space for the facility and the construction and management costs. With optimal locations for secure parking being on the first floor of parking garages there is an inherent conflict of interest for the space. Providing subsidies for tenants to use other facilities eliminates the issues associated with a conflicting right of way in parking garages.

Collaborating with the City of Toronto to provide office buildings with access to secure bicycle parking will help ensure a viable alternative for tenants looking to transition to active forms of transportation. All the buildings examined did not offer free automobile parking, so transitioning to a subsidized bicycle parking facility would provide cost incentives to employees. These cost incentives will aid in prioritizing cycling as a valid transportation option, thereby increasing its adoption (Hossain, Botma, Vandebona, \& Kiyota, 2003).

Management companies without secure bicycle parking or with inadequate supply can coordinate and collaborate with nearby City run facilities to ensure their tenants have access to secure bicycle parking facilities. The two new projects going forward at the City will enhance the ability for both parties to benefit from a synergistic relationship. With the social, environmental and health benefits associated with bicycling it is further recommended that the City continue constructing secure bicycle stations to help meet the anticipated growth in demand.

\section{Shared Facilities}

Following the premise associated with the City of Toronto bicycle stations there is also the ability for office buildings to share facilities. If one building has an excess of supply they could broker an agreement with nearby office buildings to share their facility. At the moment this is done with several facilities in Toronto, with office buildings under the same management company or a single parking authority, sharing a single secure parking facility. With many buildings in downtown Toronto connected through the PATH System it can make economic sense to create one large facility in contrast with several fragmented facilities. This could limit the costs of construction and mitigate space concerns through limiting the total number of facilities necessary. 
Existing shared facilities include:

- The Richmond Adelaide Centre shares a bike cage with all the attached office buildings;

- The Toronto Eaton Centre office buildings all share a public bicycle cage; and

- The parking authority Standard Parking manages a shared tenant bicycle cage for the Bay Wellington Tower and the TD Canada Trust Tower.

Progress in this area would create incentives for buildings with the floor area available for bicycle station expansion or creation to construct additional facilities. For buildings under the same management company this provides a cost and space efficient method of accommodating tenant demand for secure bicycle parking. For instance, First Canadian Place has a surplus of space in the secure room that could be utilized by the Exchange Plaza that is experiencing capacity constraints. Connected buildings under separate management companies can achieve the same benefit through placing the operation of the secure parking under one parking management company.

This recommendation would allow for a mutually beneficial relationship between proximal office buildings. Buildings under the same management company can ensure tenants have access to secure bicycle parking, enhancing amenities provided. In addition buildings under separate management companies can broker agreements that include financial or other forms of compensation to ensure both parties receive a fair deal. Creating shared facilities can help mitigate the barrier of providing secure bicycle parking in buildings that did not originally include them in their construction plans.

\section{Construction of Bicycle Cages}

Many older office buildings in Toronto were built before the zoning regulations surrounding secure bicycle parking were implemented, thus they are unequipped to manage an increase in demand for such facilities. While some facilities studied provided secure bicycle rooms such as the Bay Adelaide Centre and 25 York Street, retrofitting older office buildings with these facilities would be cost and space prohibitive. These separate rooms were included in the original site plans, allowing for a predetermined space allotment for their implementation, and they require a substantial capital investment. For this reason, while these rooms are typically the best option, they are not feasible to introduce into older buildings. 
Contrarily, a bicycle cage provides the most cost efficient method of providing safe and accessible secure bicycle parking. These facilities require comparably small capital investments and do not require a large amount of space. The Concordia bicycle cage cost approximately $\$ 7,800$ to construct, and carries an operational cost of $\$ 300$ dollars per year (Transport Canada, 2010; Concordia University , 2014). With controlled access given to tenants of the building the management company would not have to staff the facility and providing access could become a minor task for an existing employee. With office buildings typically wired with security cameras, placing a bicycle cage on the property would benefit from pre-existing security measures.

In addition bicycle cages are versatile and can be implemented in a range of different locations. For instance 18 York Street and the Royal Bank Plaza have their bicycle cages located outside of the building, and other buildings such as 25 York Street and the Richmond Adelaide Centre have them on the first level of their parking garage. A well secured and monitored bicycle cage provides significant deterrents to theft, allowing their implementation in otherwise unsecure areas such as beside or behind the outside of office buildings. Placing them under existing canopies or creating ceilings for the cage specifically can also further the efficacy of the facility by protecting it from the elements. For buildings with space constraints this would allow the freedom to place secure bicycle parking in a location that integrates the most effectively with their existing operations. For older office towers to meet current demand for secure bicycle parking within their own buildings the most cost and space effective method is a bicycle cage.

\section{Enhancing Safety}

One of the primary barriers for implementing and expanding secure bicycle parking was the space required. Many facilities were constructed prior to the first zoning regulations pertaining to secure bicycle parking, meaning these facilities were not initially included in the construction plans. The majority of the facilities studied were in close proximity to the entrance ramp into the parking garage, enhancing the facilities accessibility (Lefrancois, 2014). This limited the interaction between cyclists and vehicles but does not completely remove the inherent dangers. Many entrance ramps were constructed prior to the zoning regulations, without designated spaces for bicycles and vehicles. 
Placing the secure bicycle parking near the entrance ramp, despite creating barriers for expansion, improved the safety of the facility. Placing facilities deeper into the parking garage increases the interactions with vehicles, creating a more hazardous environment. For office towers that did not incorporate bicycle parking into their initial floor plan the safest method of implementation is to place them close to the entrance in a well illuminated area that limits the interaction with vehicles.

To control for these safety concerns new buildings can employ different tactics to ensure cyclists travel safely to the bicycle parking within the office building. One option, implemented by 25 York Street, is to create an extra wide and well illuminated entrance ramp with minimal blind spots. This ramp accommodates both cyclists and vehicles in a safe environment limiting the dangers of a conflicting right of way. Another option, employed by 88 Queens Quay West and the Bay Adelaide Centre, is to create a completely separate entrance. Both of these facilities have created an alternative entrance that completely removed the interactions between vehicles and bicycles within their building.

Recommendations pertaining to safety can be applied to both new and old buildings. New buildings can include safe and accessible access to secure bicycle parking into their construction plans. Older buildings that did not have that opportunity can ensure the entrance ramps and garages are well illuminated and that the facilities provided limit interactions between vehicles and bicycles through being in close proximity to the entrance ramp.

\section{Incentive Programs Within Workplaces}

Coinciding with the above recommendations would be further incentives workplaces could offer to encourage bicycling. With the benefits of cycling leading to, among other things, increases in physical and mental health organizations have a vested interest in promoting its adoption. As noted in the literature review, providing seemingly nominal financial incentives or other inducements can positively influence an individuals' propensity to cycle to work (Wardman, Tight, \& Page, 2007; Ahmed, Rose, \& Jakob, 2013). Companies can join programs such as Smart Commute to promote their existing facilities, and create organization specific events meant to further encourage employees to utilize active forms of transportation. 
All 13 of the facilities researched had paid vehicle parking, and a majority offered free bicycle parking. This cost differential can help incentivize a modal switch from automobiles to bicycles. These initiatives rest on companies such as Google with their own separate bicycle cage to implement organization level policies to encourage bicycling.

\section{Tax Incentives}

Similar to financially incentivizing employees to cycle to work the government can provide tax breaks to buildings that provide sustainable transportation options. These tax breaks could make secure bicycle parking more cost effective, removing a major barrier for implementation. This could help offset the capital and management costs associated with a secure bicycle parking facility. With bicycle cages carrying a relatively low construction cost these tax breaks would not have to be large in order to subsidize their implementation.

With physical and mental health, the environment, and traffic congestion becoming prominent political and economic issues the government has a vested interest in providing tax incentives to implement sustainable transportation options, such as secure bicycle parking. This would reaffirm the provincial and municipal government's commitment to promoting active transportation, as seen in the Provincial Policy Statement and Official Plan (City of Toronto, 2010; Ministry of Municipal Affairs and Housing , 2014).

Based on the above information the recommendation would entail an examination of the current tax structure for office towers in Downtown Toronto to assess if there is room for a sustainable transportation tax break. This would test the feasibility of tax incentives to encourage projects including secure bicycle parking.

\section{Land Use Controls from the Planning Act}

The Planning Act sets out a policy framework for land use planning in Ontario, describing how land may be controlled. For the purpose of this paper focus will be placed on Section 37: Increased density, etc., provision by-law and Section 40: Agreement exempting owner from requirement to provide parking (Government of Ontario, 2011). These land use controls could be implemented in such a manner as to encourage the implementation of secure bicycle parking.

Section 37 authorizes an increase in the height and density of development, in return for the provision of facilities, services or matters set out in the by-law (Government of Ontario, 2011). These benefits can vary significantly from the funding of public art or land 
for a park, to providing low income housing. An argument could be made to factor the provision of additional secure bicycle parking and associated amenities into the section 37 by-law agreements. As mentioned previously Toronto has set out specific secure bicycle parking zoning regulations, but with the majority of management companies researched stating they foresee an increase in demand it may be necessary to create additional facility capacity.

Section 40 pertains to an agreement between the municipality and the owner of a building regarding the provision of parking facilities (Government of Ontario, 2011). This could be utilized in office building parkades in a high density mixed use land development, with access to public transit, and with secure bicycle parking linked with on-street facilities. This could possibly remove significant construction costs associated with parking, greatly reducing the capital costs of development.

This vision for the by-law at the moment would be difficult to implement, and could lead to economic loss since all the office buildings researched still relied heavily on their parking. Buildings such as the Bay Adelaide Centre and 150 York, stated their parking lot on average were at 75 to 80 percent capacity, but during events the parking would reach capacity. Transportation in the city, while it has been shifting towards active and public modes, is still dominated by the personal automobile. For this recommendation to gain acceptance the transportation modal split in the City of Toronto would have to significantly change. Other recommendations would take precedence over land-use controls, which would require a vastly different transportation environment to be implemented effectively.

The downside to these land use controls for the research conducted in this paper are that they only apply to the creation or extensive renovation of buildings. Most of the buildings in Toronto are existing buildings, exempting them from the by-laws mentioned. In addition management companies such as Dream Office REIT are not in the business of building new buildings, rather the management of existing ones. The bicycle parking zoning by-laws in place will continue to inform new developments, and with perceptions surrounding transportation in the city changing further land use planning policy recommendations may become more feasible in the future.

Recommendations pertaining to land use controls through the Planning Act must also conform to the City of Toronto Act. This Act balances the interests of the province with that 
of Toronto, through highlighting seven key functions that the City must follow in order to provide good government (Government of Ontario, 2014). These include:

1. Determine what is in the public interest for the City.

2. Respond to the needs of the City.

3. Determine the appropriate structure for governing the City.

4. Ensure that the City is accountable to the public and that the process for making decisions is transparent.

5. Determine the appropriate mechanisms for delivering municipal services in the City.

6. Determine the appropriate levels of municipal spending and municipal taxation for the City.

7. Use fiscal tools to support the activities of the City. 2006, c. 11, Sched. A, s. 2.

(Government of Ontario, 2014)

It is thus imperative to view recommendations under the Planning Act in conjunction with the City of Toronto Act to ensure conformity. Specifically for land use controls around secure bicycle parking to have maximal effect it must consider the two first points primarily, ensure that enhanced bicycle parking is in the public interest and that it responds to needs within the City (Government of Ontario, 2014).

\section{Provincial Grants}

To encourage the City of Toronto to construct additional bicycle stations the provincial or federal government could provide grants related to the economic externalities with which they would be associated (Kitchen, 2002). Provincial grants in Ontario are usually intended to fund environmental projects, and to a lesser degree transportation. A case could be made that through increasing the cycling modal share through end-of-trip facilities both those goals could be positively benefited. These costs are not easily quantifiable or related to particular individual initiatives, making the creation of bicycle station specific grants a difficult tool to implement on the basis of a cost-benefit analysis. Grants could be earmarked for municipal projects and initiatives that promote population health and reduced emissions leading to capital being allotted to aiding in the creation and management of bicycle stations. Ultimately it is difficult to measure the spillovers and the rate at which these expenditures 
should be subsidized, but that does not negate the necessity for providing grants that address spillovers.

As highlighted in this paper there are numerous funding models associated with the creation and management of a secure bicycle parking facility that rely on numerous factors and conditions. Financing additional bicycle stations in the city through grants and other initiatives can build off the existing momentum from the past several years of pushing active transportation as a viable utilitarian mode of transportation. Examining the funding opportunities and future potential for secure parking in Toronto represent a small subsection of the important task of promoting active transportation as an efficient and safe utilitarian mode of transportation. Grants, if implemented, could assist Toronto towards creating a healthier more vibrant community through minimizing road congestion, bettering the environment, and promoting overall population health.

With the province in the past downloading expenditure responsibilities onto municipalities the role of grants has diminished over time (Kitchen, 2002). With congestion, health, and environmental issues becoming ever pressing societal issues the political environment may be such to reintroduce certain grants.

Recognizing that Provincial grants do not represent a large income generating tool it is still valuable to visit the possibility of it being utilized in a manner to encourage active transportation. An increase in the adoption of active transportation can benefit the province through a range of positive externalities. Essentially the provincial government receives the benefit of increased active transportation while the City of Toronto and organizations in the city cover the brunt of the associated expenditure. Providing government grants would allow more accelerated progress towards enhancing the bicycle modal share, with secure bicycle parking representing a significant opportunity for growth. 


\section{DISCUSSION}

\section{Different Recommendations for Different Facilities}

Each of these recommendations proposes a method of funding and providing safe and secure bicycle parking at end-of-trip facilities. With the diversity in office buildings in downtown there is no singular best practice for provisioning secure bicycle parking. Each building should be analyzed on a case-by-case basis to figure out the recommendation that best fits its individual characteristics. Thus the recommendations listed above will serve as a guide that should be applied with regard to the specific characteristics of the building in question.

\section{Future Research Potential}

Expansion of this research could focus on several key areas not focused on in this paper. The primary data collected for this research focused on the provision of secure bicycle parking and its associated amenities in downtown Toronto. Expanding on this could entail individual or tenant specific interviews. This would provide a more encompassing analysis of the strengths and weaknesses from the perspective of its users, to be analyzed in conjunction with the providers of the facilities. Those interviewed would be able to provide a qualitative account of their experiences utilizing the facility, and potential improvements that they could see positively benefiting the provision of secure bicycle parking.

Further research could be conducted through interviewing individuals involved with creating new office building developments. Land use planning by-laws can provide additional secure bicycle parking as mentioned in the recommendations, but they pertain to new developments. Interviews with those involved with the creation of buildings would provide insight into their perspectives surrounding the provision of additional secure bicycle parking spaces. Recommendations pertaining to land use controls would have the greatest benefit when associated with the construction process of new buildings.

Existing office buildings could also be examined to ensure conformity to their applicable bicycle zoning by-laws. This would involve researching the individual buildings construction agreements to see how much, if any, secure bicycle parking they had in their zoning. Researching this would provide valuable information on whether existing buildings are oversupplying, undersupplying, or provide exact secure bicycle parking as per their zoning. This would also give insight into whether purpose built bicycle parking has been 
transferred to general storage or a function alternative to its purpose. With secure bicycle parking zoning in the research area dating back to the early 1990s this would be a valuable extension of the research.

Another potential area for research would be to assess the provision of bicycle parking in office buildings outside of the downtown core, and creating a comparative analysis based on those findings. This would assist in illustrating the transportation modal differences between urban and suburban land developments and the association with supportive infrastructure such as bicycle lanes. Similar to the analysis of buildings downtown this could focus on the available facilities, with expansion into interviews pertaining to the strengths and barriers to encouraging cycling through the provision of secure end-of-trip facilities. Both of these potential research expansions would positively benefit the goal of this paper to examine how best to encourage a higher transportation modal share for utilitarian bicycling. 


\section{APPENDIX}

\section{Appendix A. Survey Questions}

1. Does your building offer secure bicycle-parking facilities?

a. If yes what facilities are offered? And what is the quantity of the spaces provided? (Bicycle cage, bicycle room, bicycle lockers, etc.)

b. Are there any amenities offered alongside the secure facilities? (Bicycle repair equipment, bike pump, showers, lockers, etc.)

2. If there is a facility is there adequate supply to meet the demand for secure bicycle parking?

a. Do you foresee an increase in the demand for secure bicycle parking?

b. What demand management techniques do you use to assess current and future demand?

3. What do you foresee as potential barriers to implementing secure bicycle parking?

4. What is the cost for tenants to use the bike room?

5. What is the cost for a monthly vehicle-parking pass? 


\section{BIBLIOGRAPHY}

20 VIC Management Inc. (2015). One Queen - 20 RIchmond Street East. Retrieved from One Queen Street East: http://www.onequeenstreeteast.com/

Ahmed, F., Rose, G., \& Jakob, C. (2013). Commuter Cyclist Travel Behavior . Transportation Research Board of the National Academies, 76-82.

Arnoldi, J., West, K., \& Gilligan, S. (2014). Greater Toronto Area Office Market Report Fourth Quarter 2014. Toronto: Colliers International .

Board of Science of the British Medical Association. (2012). Healthy transport = Healthy lives. London: British Medical Association.

Brookfield . (2015). Bay Adelaide Centre. Retrieved from Brookfield Office Properties: http://www.brookfieldofficeproperties.com/content/bay_adelaide_centre/bay_adelaide _centre-5263.html

Brookfield. (2015). Brookfield Place Bay Wellington Tower. Retrieved from Brookfield Office Properties https://www.brookfieldofficeproperties.com/content/brookfield_place_bay_wellington _tower/brookfield_place_bay_wellington_tower-10928.html

Brookfield. (2015). Exchange Tower. Retrieved from Brookfield Office Properties: https://www.brookfieldofficeproperties.com/ca/toronto/exchange-tower

Brookfield. (2015). First Canadian Place. Retrieved from Brookfield Office Properties: http://brookfieldofficeproperties.com/content/first_canadian_place/first_canadian_pla ce-5575.html

Buehler, R. (2012). Determinants of bicycle commuting in the Washington, DC region: The role of bicycle parking, cyclist showers, and free car parking at work. Transportation Research Part D 17, 525-531.

City of Chicago. (2014). Bike Parking. Retrieved from City of Chicago: http://www.cityofchicago.org/city/en/depts/cdot/provdrs/bike/svcs/bike_parking.html

City of Toronto. (2010). Toronto Official Plan. Toronto: City of Toronto. 
City of Toronto. (2013). City of Toronto Zoning By-Law. Toronto: City of Toronto.

City of Toronto. (2014). Bicycle Parking Stations. Retrieved from City of Toronto: http://www1.toronto.ca/wps/portal/contentonly?vgnextoid=c645970aa08c1410VgnVC M10000071d60f89RCRD

City of Toronto. (2015). Data Catalogue - Locations and mapping. Retrieved from City of Toronto:

http://www1.toronto.ca/wps/portal/contentonly?vgnextoid=75d6e03bb8d1e310VgnVC M10000071d60f89RCRD

City of Vancover. (2012). Parking By-law Section 6: Off-street Bicycle Space Regulations. Vancouver: City of Vancouver.

City Planning Division. (2015). Ward Profiles. Retrieved from City of Toronto: http://www1.toronto.ca/wps/portal/contentonly?vgnextoid=2394fe17e5648410VgnVC M10000071d60f89RCRD

Concordia University . (2014). Sustainable Transportation. Retrieved from Concordia University Montreal: http://www.concordia.ca/campuslife/sustainability/transportation.html

Cycling Infrastructure and Programs. (2008). Guidelines for the Design and Management of Bicycle Parking Facilities. Toronto: City of Toronto.

Dream Office REIT. (2015). 18 King Street East. Retrieved from Dream Office REIT: http://leasing.dream.ca/building.php?building=18-king-street-east\#summary

Dream Office REIT. (2015). 655 Bay Street. Retrieved from Dream Office REIT: http://leasing.dream.ca/building.php?building=655-bay\#summary

Dream Office REIT. (2015). Adelaide Place. Retrieved from Dream Office REIT: http://leasing.dream.ca/building.php?building=150-york-st\#summary

Environment Canada. (2013, October 9). Pollution Prevention. Retrieved from Government of Canada: http://www.ec.gc.ca/p2/Default.asp?lang=En\&n=88D8B369-1

Fox, K. (1999). The influence of physical activity on mental well-being. Public Health Nutrition, 411-418. 
Frank, L., Engelke, P., \& Schmid, T. (2003). Health and Community Design. Washington: Island Press.

Government of Ontario. (2011). Planning Act. Toronto: Government of Ontario.

Government of Ontario. (2014). City of Toronto Act, 2006. Toronto: Government of Ontario.

Heinen, E., Van Wee, B., \& Kees, M. (2010). Commuting by bicycle: An Overview of the Literature . Transport Reviews: A Transnational Transdisciplinary Journal, 59-96.

Hossain, Q. S., Botma, H., Vandebona, U., \& Kiyota, M. (2003). Acceptable Access Distance to Bicycle Parking Facilities. Washington: Transportation Research Board.

Hunt, J., \& Abraham, J. (2007). Influences on bicycle use. Transportation, 453-470.

Ipsos Reid. (2010). City of Toronto Cycling Study. Toronto: Ipsos.

Kitchen, H. (2002). Municipal Revenue and Expenditure Issues in Canada . Toronto: Canadian Tax Foundation .

Lefrancois, C. B. (2014). Secure Bike Parking in Vancouver: Local \& Regional Context, Best Practices, and Recommendations for an EasyPark Pilot. Vancouver: Greenest City Scholar Program.

Martens, K. (2004). The bicycle as a feedering mode: experiences from three European countries. Transportation Research Part D 9, 281-294.

Martens, K. (2007). Promoting bike-and-ride: The Dutch experience . Transportation Research Part A 41, 326-338.

Menkes. (2015). 25 York Street. Retrieved from Menkes Business Storeys: http://www.menkes.com/telus/

Ministry of Municipal Affairs and Housing . (2014). 2014 Provincial Policy Statement. Toronto: The Government of Ontario.

NYC Department of City Planning. (2008). Zoning for Bicycle Parking. New York: The City of New York. 
Oja, P., Titze, S., Bauman, A., de Geus, B., Krenn, P., Reger-Nash, B., \& Kohlberger, T. (2011). Health benefits of cycling: a systematic review. Scandinavian Journal Of Medicine \& Science In Sports, 496-509.

Ostler, T. (2014). Trends Issues Intensification Downtown Toronto. Toronto: City of Toronto, City Planning.

Oxford Properties Group . (2015). Richmond Adelaide Centre. Retrieved from Oxford: http://www.oxfordproperties.com/leasing/en/office/property/111-richmond-st-west

Oxford Properties Group. (2015). 88 Queens Quay . Retrieved from Oxford: http://www.oxfordproperties.com/leasing/en/office/property/88-queens-quay-west

Oxford Properties Group. (2015). Royal Bank Plaza. Retrieved from Oxford: http://www.oxfordproperties.com/leasing/en/office/property/royal-bank-plaza-northtower

Pucher, J., \& Buehler, R. (2009). Integrating Bicycling and Public Transport in North America. Journal of Public Transportation, Vol. 12, No. 3, 79-104.

Pucher, J., Dill, J., \& Handy, S. (2010). Infrastructure programs, and policies to increase bicycling: An international review. Preventitive Medicine, Volume 50, S106-S125.

Rietveld, P. (2000). The accessibility of railway stations: the role of the bicycle in the Netherlands. Transportation Research Part D 5, 71-75.

San Francisco County Transportation Authority. (2013). Strategy for Long-Term Bicycle Parking in San Francisco. San Francisco: SFMTA.

Statistics Canada. (2006). Commuting Patterns and Places of Work of Canadians, 2006 Census . Ottawa: Government of Canada.

Sully, A. (2006). Workplace cycle parking guide. London: Transport for London.

The Cadillac Fairview Corporation Limited. (2011). Toronto Eaton Centre Office Properties. Retrieved from Cadillac Fairview: http://www.tectowers.com/en/Pages/default.aspx

The Government of Western Australia. (2013). TravelSmart Workplace fact sheet. Perth: The Department of Transport. 
Third Wave Cycling Group. (2010). Cycling Support Services Study: Pilot Bicycle Station Implementation Plan. Vancouver: Third Wave Cycling Group Inc.

Toronto and Region Conservation Authority and Greater Toronto CivicAction Alliance. (2011). The Living City Report Card. Toronto: Toronto and Region Conservation Authority and Greater Toronto CivicAction Alliance.

Transport Canada. (2010). Bicycle End-of-Trip Facilities. Ottawa: Transport Canada.

Urban Systems. (2011). Bicycle Parking Strategy. Victoria : Urban Systems.

Wardman, M., Tight, M., \& Page, M. (2007). Factors influencing the propensity to cycle to work. Transportation Research Part A 41, 339-350.

Winters, M., Davidson, G., Kao, D., \& Teschke, K. (2011). Motivators and deterrents of bicycling: comparing influences on decisions to ride. Transportation, 153-168.

World Weather Online. (2015). Toronto Yearly Weather Summary. Retrieved from World Weather Online: http://www.worldweatheronline.com/Toronto-weatheraverages/Ontario/CA.aspx 